\title{
ДОСВІД БАТИМЕТРИЧНОГО МОДЕЛЮВАННЯ ТА ЛАНДШАФТНОГО КАРТОГРАФУВАННЯ ОЗЕР ПОЛІСЬКОГО РЕГІОНУ УКРАЇНИ
}

\author{
Мартинюк В. О., Андрійчук С. В., Зубкович I. В.
}

\section{ВСТУП}

Висока заозереність Поліського регіону України спонукає до розробки сучасних методів кадастрової оцінки озер 3 урахуванням ступеня геоекологічного стану їхніх водозборів ${ }^{1}$, формування озерно-басейнових природно-господарських моделей на засадах збалансованого природокористування. Створення сучасної кадастрово-ресурсної бази озер дозволить розробити стратегію їхнього раціонального використання та охорони у світлі адаптації територіальних і аквальних ландшафтних комплексів до змін клімату. Багаторічні ландшафтно-лімнологічні дослідження (1995-2020 рр.) у межах Поліського регіону, зокрема Волинського Полісся, дозволили отримати досвід інструментальних польових пошуків 3 гідрологічного профілювання, геологічного зондування донних осадів, батиметричного та ландшафтного картографування озер. У даній роботі ми хочемо акцентувати увагу на розроблюваних батиметричних моделях озер, які служать передумовою для створення ландшафтних карт природних аквальних комплексів.

Комплексні польові дослідження озер Волинського Полісся у 20-30-х роках XX ст. проводили польські вчені, зокрема С. Лєнцевич ${ }^{2}$ Е. Рюллє $\epsilon^{3}, \epsilon$. Кондрацький ${ }^{4}$ та інші. Ними були створені батиметричні картосхеми на понад 70 озер Волинського Полісся та розраховані основні морфометричні і гідрологічні параметри цих водойм. Сьогодні ці матеріали служать відправною точкою для порівняння сучасних лімнічних характеристик озер території дослідження.

У 70-80-х роках XX ст. співробітниками Львівського університету, зокрема М. Зденюком, Б. Мухою, Н. Карпенко, Г. Проць, С. Худзиком та іншими вченими проводилися ландшафтно-лімнологічні пошуки водойм

\footnotetext{
1 Зубкович I.В., Мартинюк В.О. Особливості антропогенного навантаження на ландшафти Волинського Полісся у контексті геоекологічної діагностики озерно-басейнових систем. Actual problems of natural sciences: modern scientific discussions : collective monograph. Riga : Izdevniecība "Baltija Publishing", 2020. C. 220-242. DOI https://doi.org/10.30525/978-9934-588-45-7.13.

${ }^{2}$ Lenzewicz St. Miedzyrzecze Bugu i Prypeci. Wody plynace i jeziora. Przeglad geogr. 1931. T. 11. S. 5-28.

${ }^{3}$ Rühle E. Jeziora krasowe zachodniej czesci Polesia Wołyńskiego. Rocznik Wolynski. Równe, 1935. T. IV. S. 210-241.

${ }^{4}$ Kondracki J. Katalog jezior poleskich. Prace, wykonane w zakladzie geogr. Universytety w Warszawe. 1938. № 24. S. 19-35.
} 
Шацького поозер'я ${ }^{5,6}$. В 90-х роках XX ст. виходять роботи Л. Ільїна, які грунтуються на польових спостереженнях озер Волині й містять інформацію 3 кадастру та батиметрії озер ${ }^{7,8,9}$. У 2012 р. А. Хоїнські, Л. Ільїним та іншими вченими було побудовано цифрову батиметричну карту оз. Світязь та уточнено параметричні зміни водойми протягом 1929-2012 pp. ${ }^{10}$. Сьогодні батиметричні спостереження озер Шацького поозер'я проводяться Шацькою міжвідомчою науково-дослідною екологічною лабораторією Фізико-механічного інституту імені Г. В. Карпенка НАН України, передусім оз. Світязь ${ }^{11}$. Низка батиметричних карт озер Волинського Полісся побудована співробітниками Інституту телекомунікацій і глобального інформаційного простору НАН України $^{12}$. Більш детально результати власних батиметричних та ландшафтних пошуків озер Волинського Полісся розглянемо нижче.

\section{1. Батиметричні моделі озер Поліського регіону}

Матеріалами дослідження слугували польові методи лімнологічного профілювання, що проводилися експедиційним загоном кафедри екології, географії та туризму Рівненського державного гуманітарного університету протягом 2010-2019 pp. У результаті польових досліджень було обстежено понад 50 озер, що розташовані у різних фізикогеографічних районах (ФГР) Волинського Полісся (рис. 1, табл. 1).

Проміри глибин здійснювали з льоду із використанням рибальського льодового бура та ехолота Lycky FFW718 (безпровідний), географічні координати точок вимірювання глибин та гіпсометричних профілів водойми фіксували за допомогою GPS-навігатора Garmin Oregon 650 (рис. 2). Польові матеріали гідрологічного профілювання заносили у щоденник та формували комп'ютерну базу даних озер в середовищі Excel (рис. 3).

\footnotetext{
5 Проць Г.Л., Зденюк М.В. Ландшафтно-лімнологічні дослідження Шацького поозер'я. Вісник Львів. ун-ту. Серія «Географія». 1980. Вип. 12. С. 72-77.

${ }^{6}$ Проць Г.Л., Карпенко Н.И., Худзик С.Р. и др. Ландшафтные картосхемы озер Люцимер и Черное. Вестник Львов. ун-та. Серія «Геологія». 1986. Вып. 9. С. 11-14.

7 Ільїн Л.В. Сучасний стан, динаміка, конструктивні основи раціонального використання та охорони озер Волинської області : дис. ... канд. геогр. наук : 11.00.11 ; Львівський держ. ун-т ім. Івана Франка. Львів, 1996. 258 с.

${ }^{8}$ Ільїн Л.В., Мартинюк Л.В. Озера України : довідник. Львів : Ред.-видав. відділ Львів. держ. унту, 1998. $52 \mathrm{c.}$

${ }^{9}$ Ільїн Л.В., Мольчак Я.О. Озера Волині : Лімно-географічна характеристика. Луцьк : Надстир'я, 2000. $140 \mathrm{c}$.

${ }^{10}$ Choiński A., Ilyin L., Ptak M., Strzelczak A. Zmiana batymetrii jeziora Świtaź w latach 1929-2012. Природа Західного Полісся та прилеглих територій. Луцьк, 2012. № 9. С. 55-59.

11 Альохіна О.В., Корусь М.М., Кошовий В.В., Мельник М.М., Муравський Л.І., Сидорук І.В., Юрчук П.В. Батиметричні дослідження озера Світязь: минуле, сучасність та перспективи. Природа Західного Полісся та прилеглих територій. 2014. № 11. С. 24-32.

12 Трофимчук О.М., Мокрий В.І., Радчук В.В., Радчук I.В., Загородня С.А. Інформаційне забезпечення гідроакустичного моніторингу озер Західного Полісся. Екологічна безпека та природокористування. Київ, 2015. Вип. 1 (17). С. 5-15.
} 


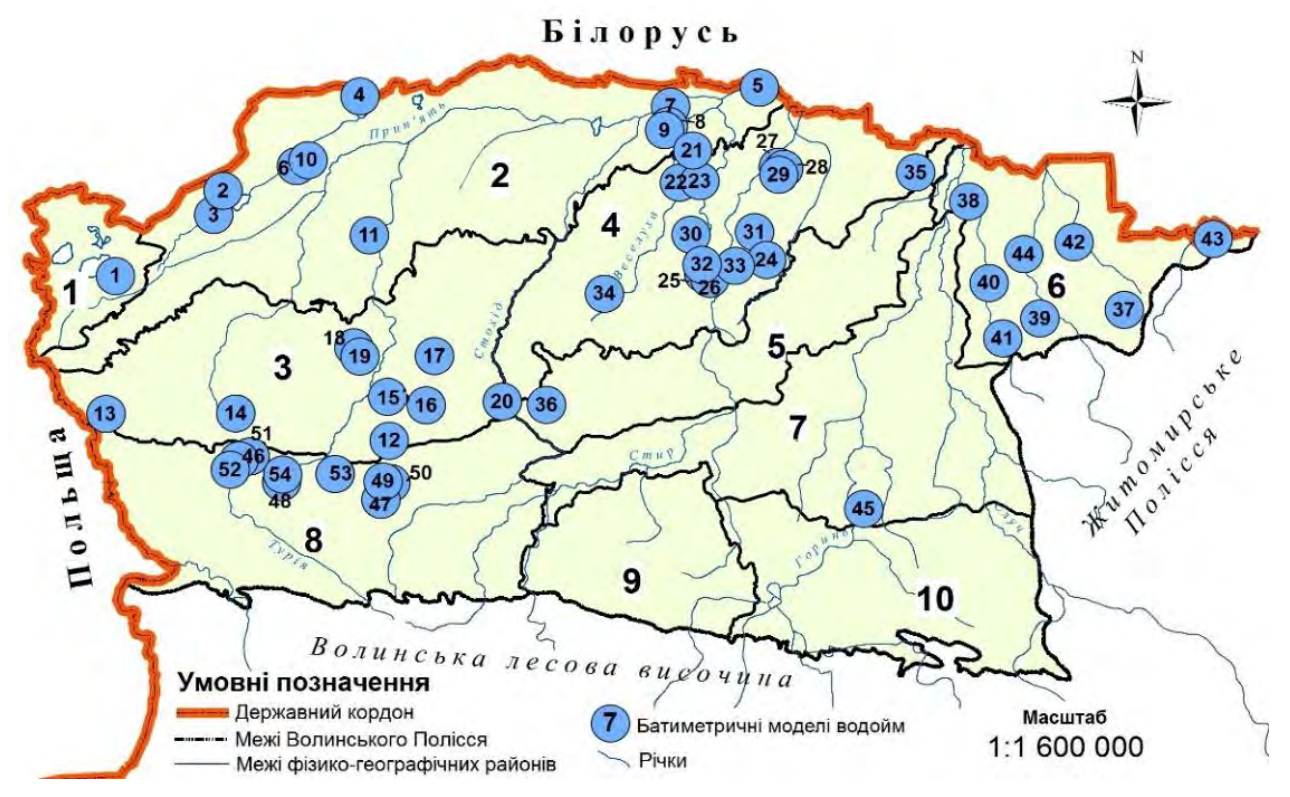

\section{Рис. 1. Польові гідрологічні обстеження озер Волинського Полісся протягом 2010-2019 pp. ${ }^{13}$}

Умовні позначення до рис. 1:

Фізико-географічна область - Волинське Полісся.

Підобласть - Верхньоприп'ятське Полісся.

Фізико-географічні райони: 1. Шацький. 2. Верхньоприп'ятський. 3. ЛюбомльськоКовельський. 4. Нижньостирський.

Підобласть - Буго-Горинське Полісся.

Фізико-географічні райони: 5. Маневицько-Володимирецький. 6. Льва-Горинський. 7. Колківсько-Сарненський. 8. Турійсько-Рожищенський. 9. Ківерцівсько-Цуманський. 10. Костопільсько-Березнівський.

Таблиця 1

Модельні озера польових гідрологічних обстежень *

\begin{tabular}{|c|l|c|l|}
\hline $\begin{array}{c}\text { № } \\
\text { 3/I }\end{array}$ & \multicolumn{1}{|c|}{ Назва озера } & $\begin{array}{c}\text { № } \\
\text { 3/II }\end{array}$ & \multicolumn{1}{c|}{ Назва озера } \\
\hline 1 & \multicolumn{1}{|c|}{2} & 3 & \multicolumn{1}{c|}{4} \\
\hline 1 & Чорне Велике (смт. Шацьк) & 28 & Чорне (с. Вовчиці) \\
\hline 2 & Святе (Дружба) & 29 & Озерце (с. Вовчиці) \\
\hline 3 & Ковпине & 30 & Любинське \\
\hline 4 & Засвяття & 31 & Луко \\
\hline 5 & Сосно & 32 & Журавлине (с. Журавлине) \\
\hline 6 & Радожичі & 33 & Запрудське \\
\hline 7 & Засвітське & 34 & Охнич \\
\hline 8 & Посвітське & 35 & Велике Почаївське \\
\hline
\end{tabular}

\footnotetext{
${ }^{13}$ Мартинюк В.О., Зубкович І.В., Андрійчук С.В. Батиметричне моделювання озер Волинського Полісся для потреб їхнього ландшафтного картографування. Географія та екологія: наука і освіта : збірник матеріалів 8 Всеукр. наук.-практ. конф. 3 міжнар. участю, м. Умань, 9-10 квітня 2020 р. Умань : Візаві, 2020. С. 116-121.
} 
Закінчення табл. 1

\begin{tabular}{|c|l|c|l|}
\hline 1 & \multicolumn{1}{|c|}{2} & 3 & \\
\hline 9 & Задовже & 36 & Світле \\
\hline 10 & Мшане & 37 & Більське \\
\hline 11 & Вінок & 38 & Миляцьке \\
\hline 12 & Любитівське & 39 & Тухове \\
\hline 13 & Ягодинське & 40 & Стрільське \\
\hline 14 & Сомине (с. Сомин) & 41 & Сомине (с. Рудня Карпилівська) \\
\hline 15 & Білинське & 42 & Крисине \\
\hline 16 & Уховецьке & 43 & Сомитське \\
\hline 17 & Кричевичське & 44 & Велике (с. Великі Озера) \\
\hline 18 & Велике (с. Облапи) & 45 & Мар'янівське \\
\hline 19 & Мале (с. Облапи) & 46 & Дольське \\
\hline 20 & Озерненське (с. Озерне) & 47 & Озерянське (с. Озеряни) \\
\hline 21 & Горіхове (с. Храпин) & 48 & Велище \\
\hline 22 & Острівське & 49 & Пересіка \\
\hline 23 & Велике (с. Острівськ) & 50 & Погоріле \\
\hline 24 & Воронківське & 51 & Святе (с. Туричани) \\
\hline 25 & Двірське & 52 & Туричанське \\
\hline 26 & Кримне & 53 & Тагачинське \\
\hline 27 & Біле (с. Вовчиці) & 54 & Селище (с. Соловичі) \\
\hline
\end{tabular}

*Локалізація озер показана на рис. 1

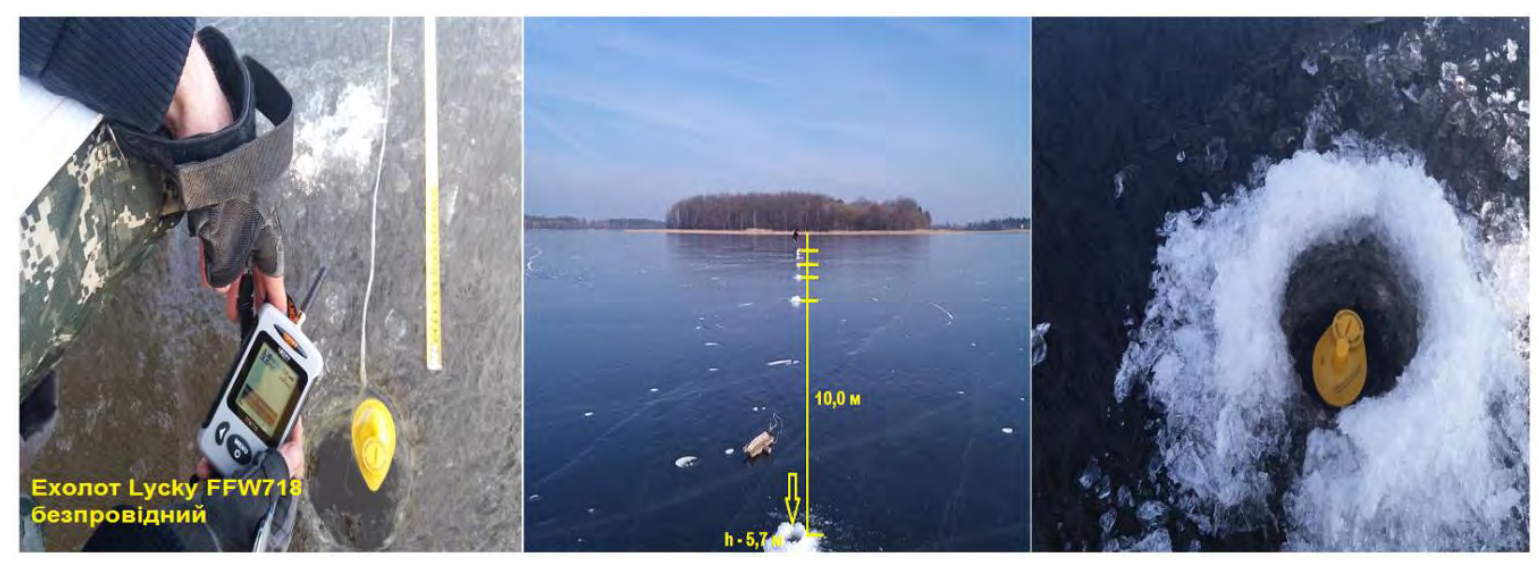

Рис. 2. Гідрологічне профілювання на оз. Задовже

Алгоритм створення цифрової батиметричної карти озера у програмному середовищі ArcMap 10.3 включає такі операції: підвантаження космознімку водойми високої роздільної здатності (з pecypcy SASPlanet), який має просторову прив'язку (систему координат WGS 84); створення шару для оцифрування периметру (контурів берегової лінії), а також шару заростів вищої водної 498 
рослинності водойми, які добре дешифруються на космознімках; виконання просторової прив'язки гідрометричних поперечників водойми на космознімку з точками вимірювання глибин; побудова гідрологічних профілів озера 3 метою уточнення крутизни схилів улоговини та особливостей диференціації еколого-ландшафтних зон (літоральної, субліторальної, профундальної) водойми; укладання векторних ліній (ізоліній) через точки 3 однаковими глибинами гідрометричних поперечників озера; створення батиметричної картографічної моделі (масштабування, класифікація за кольоровою гамою водних мас 3 однаковими глибинами, підписи ізобат, формування «врізки» легенди та масштабної лінійки). Батиметрична модель оз. Посвітське та гідрологічні профілі цього ж озера наведені на рис. 4-5.

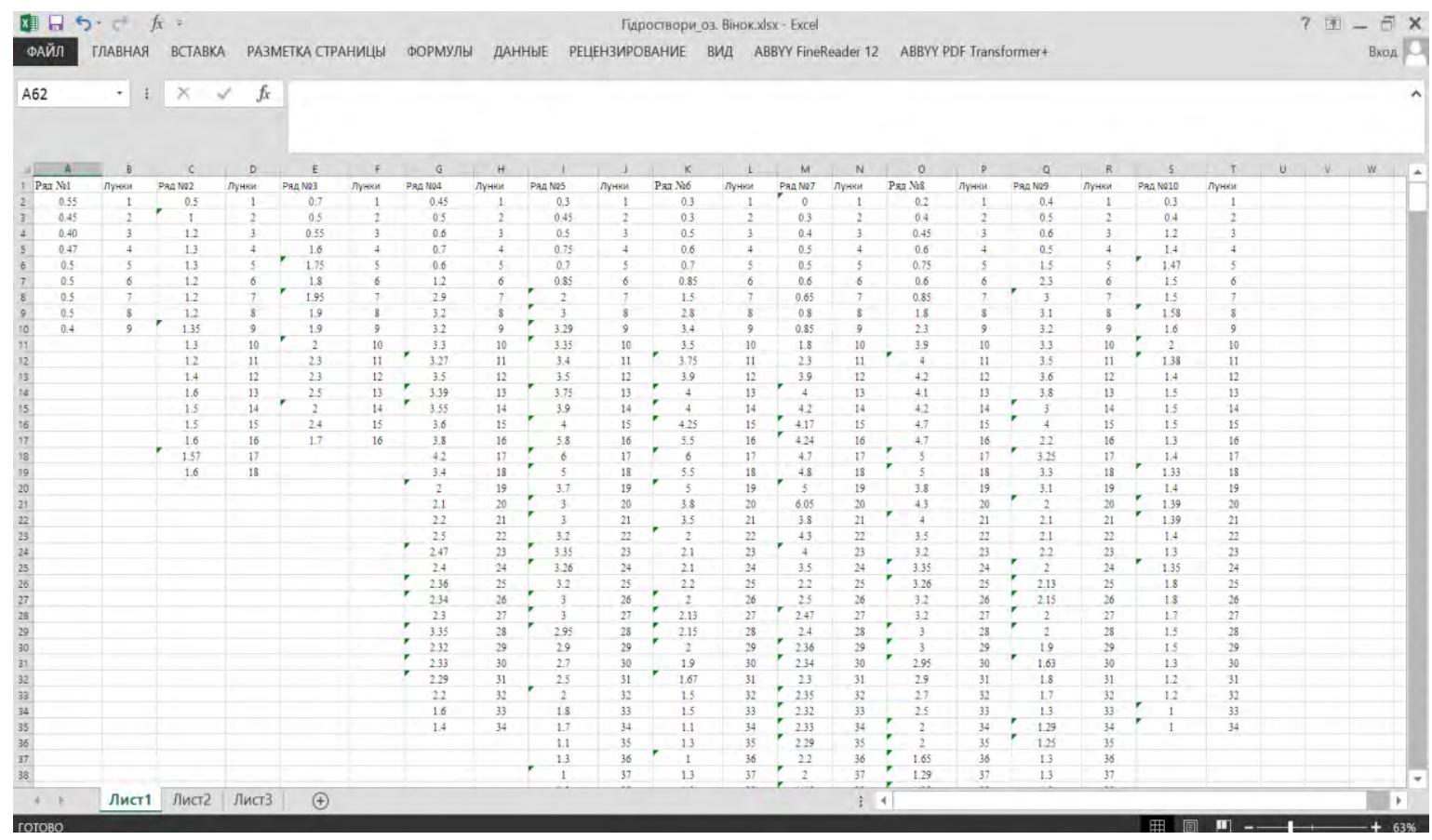

Рис. 3. Робочий файл внесених даних гідрологічних промірів глибин оз. Вінок за окремими поперечниками

Розглянемо результати батиметричного картографування восьми модельних озер Волинського Полісся та особливості їхніх морфологоморфометричних характеристик (рис. $6 a-6 b$ ). Усі водойми локалізовані у Турійсько-Рожищенському ФГР, за винятком оз. Мале Облапське, що сформувалося в Любомльсько-Ковельському ФГР. Озера малі за площею - від 2,53 га (оз. Мале Облапське) до 21,18 га (оз. Дольське). Розташування озер за гіпсометричними рівнями знаходиться у межах 170,4-186,3 м н.р.м. (табл. 2). 


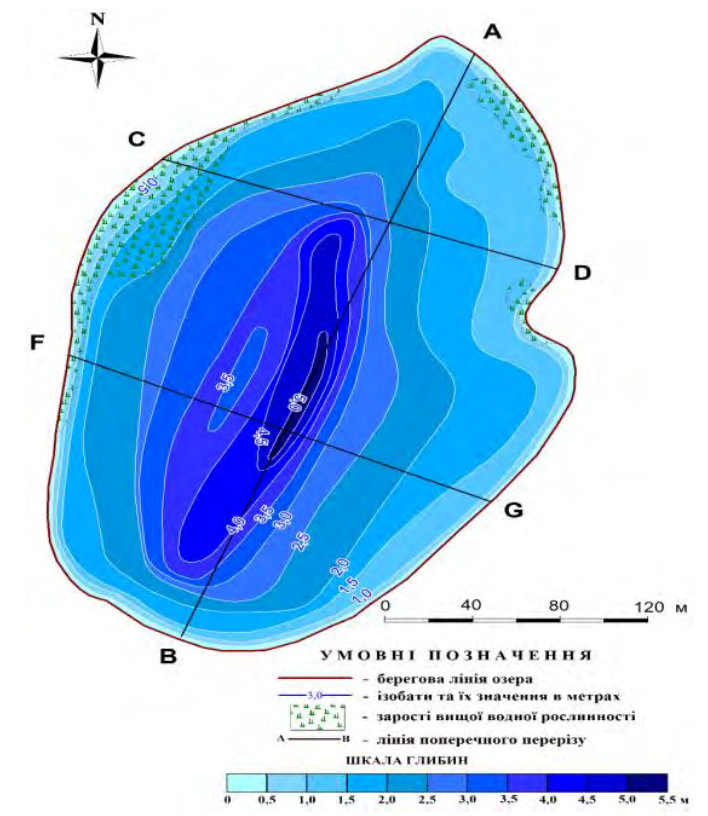

Рис. 4. Батиметрична модель оз. Посвітське

Генетичні особливості формування озер Волинського Полісся частково пов'язані 3 постгляціальними етапами плейстоценових зледенінь, особливо окського (500-410 тис. років) та дніпровського (290-240 тис. років), які знівелювали нерівності осадового чохла, що сформувався у неогеновому i палеогеновому періодах ${ }^{14}$. Більшість дослідників, які обгрунтовують генезис озер акцентують увагу, що активізація закладання озерних улоговин розпочалася набагато пізніше, близько $10,5-12,0$ тис. років тому ${ }^{15,16}$. Близьке залягання крейдових відкладів до денної поверхні у межах території дослідження сприяло карстоутворенню, а відтак заповнення цих пустот підземними водами верхньокрейдового горизонту. Такі міркування обгрунтовані інструментальними лімнологічними пошуками, рисунками конфігурації ізобат батиметричних моделей озер (рис. $6 a-6 b$ ), а також аналізом складу й потужності четвертинних відкладів та гідрогеологічних особливостей Волинського Полісся. Безперечно, у межах Волинського Полісся поширені й інші генетичні групи озер, зокрема реліктові, льодовикові, льодовиково-ерозійні, карстово-тектонічні, карстово-суфозійні, заплавні тощо.

\footnotetext{
14 Зубкович І.В., Мартинюк В.О. Особливості ландшафтної структури Волинського Полісся (за результатами польових досліджень на ключових ділянках). Наук. записки Сумського ДПУ імені А.C. Макаренка. Серія «Географічні науки». 2020. Том 2. Вип. 1. С. 3-18. DOI: doi.org/10.5281/ zenodo.3727228.

${ }^{15}$ Ільїн Л.В. Лімнокомплекси Українського Полісся : монографія : У 2-х т. Т. 1: Природничогеографічні основи дослідження та регіональні закономірності. Луцьк : РВВ «Вежа» Волин. нац. унту імені Лесі Українки, 2008. 316 с.

${ }^{16}$ Dobrowolski R., Bałaga K., A. Bogucki et al. Chronostratigraphy of the Okunin and Czerepacha lakemire geosystems (Volhynia Polesiye, NW Ukraine) during the late glacial and holocene. Geochronometria. 2001. Vol. 20. P. 107-115.
} 

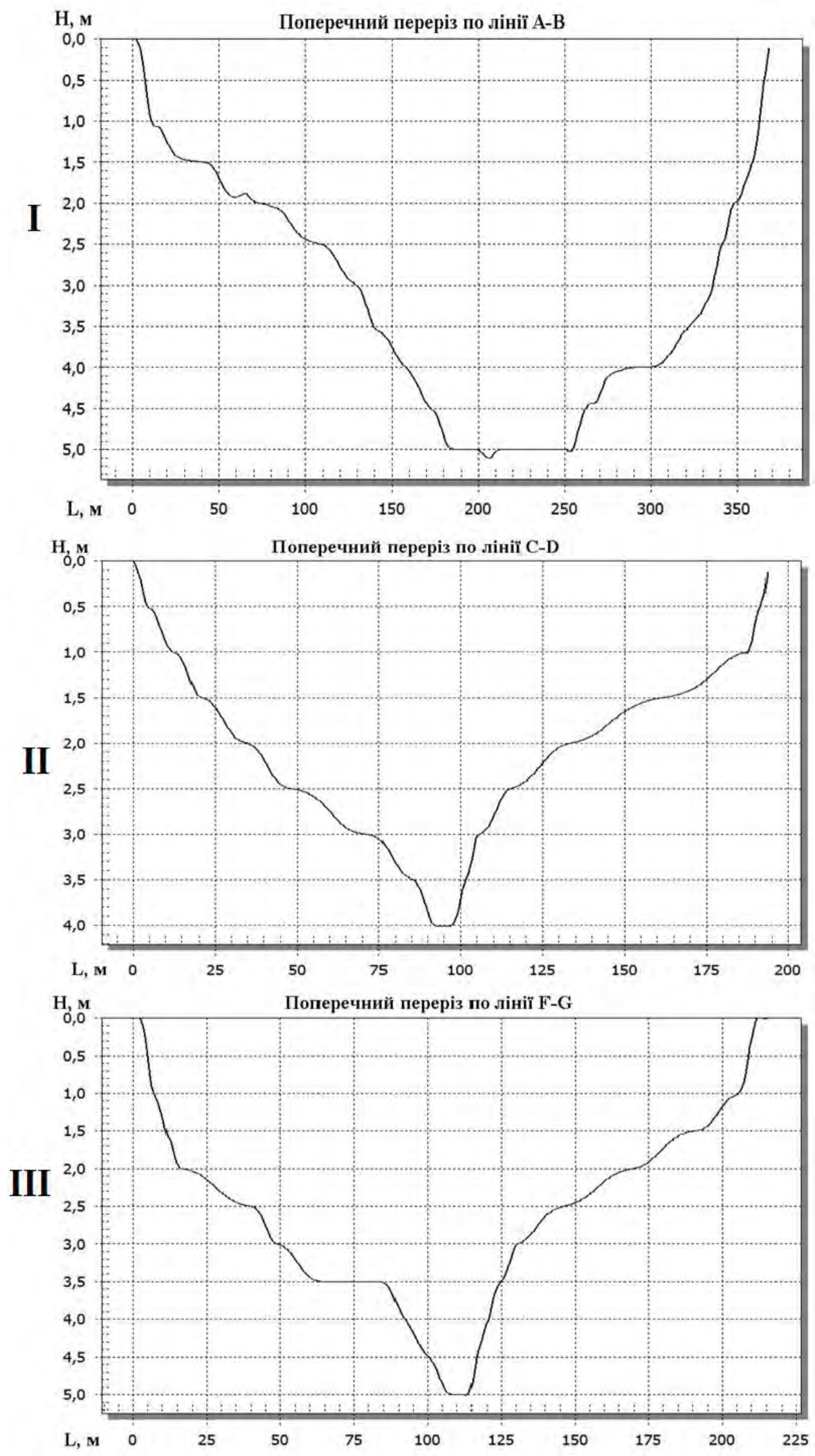

Рис. 5. Гідрологічні профілі оз. Посвітське 


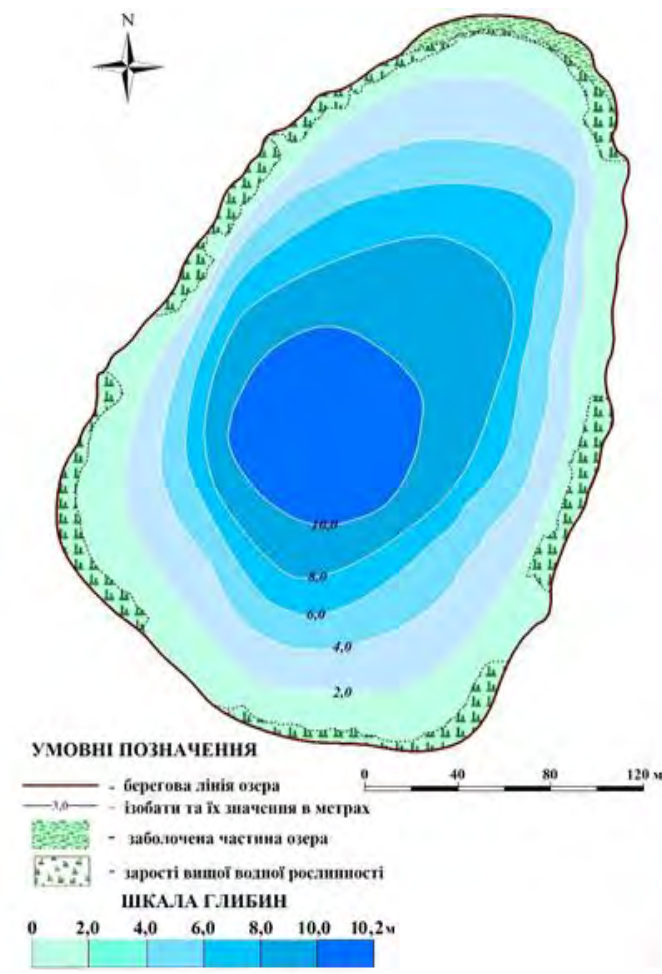

Озеро Велище

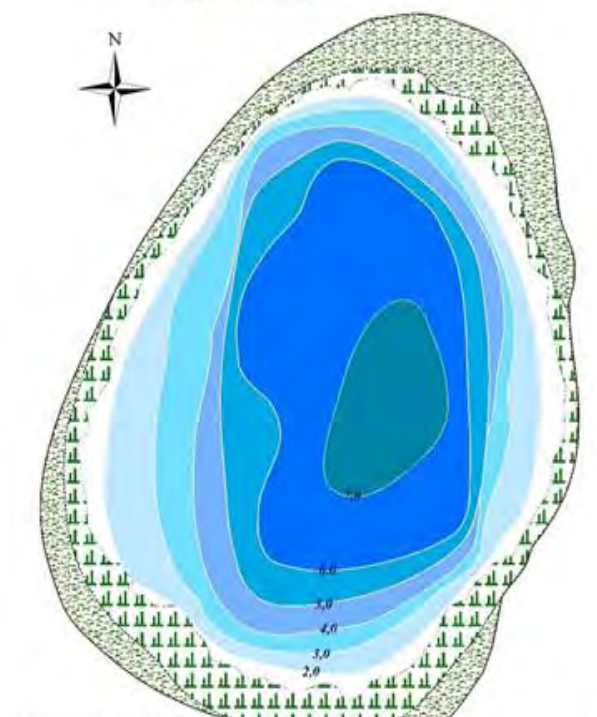

УмОВН познАчЕнН

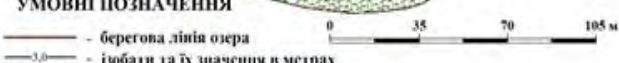

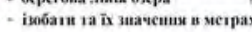

safюлочена частина оsep

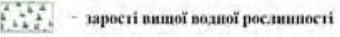

ШКА.ЛА ГЛИБИН

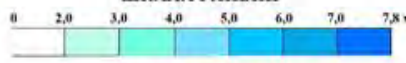

Озеро Погоріле
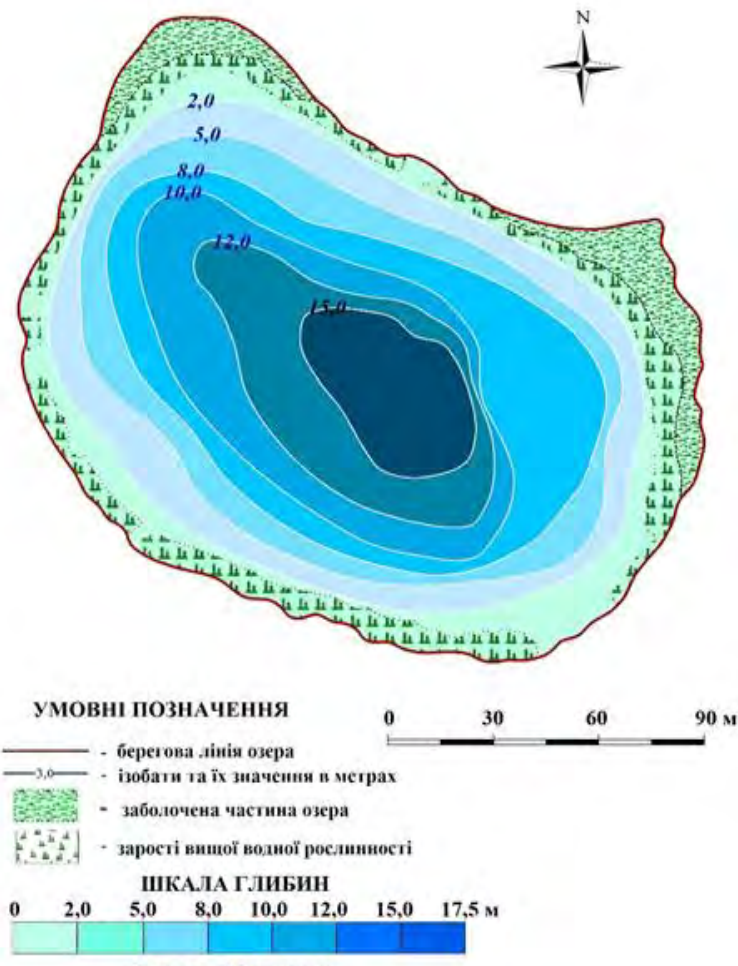

Озеро Дольське
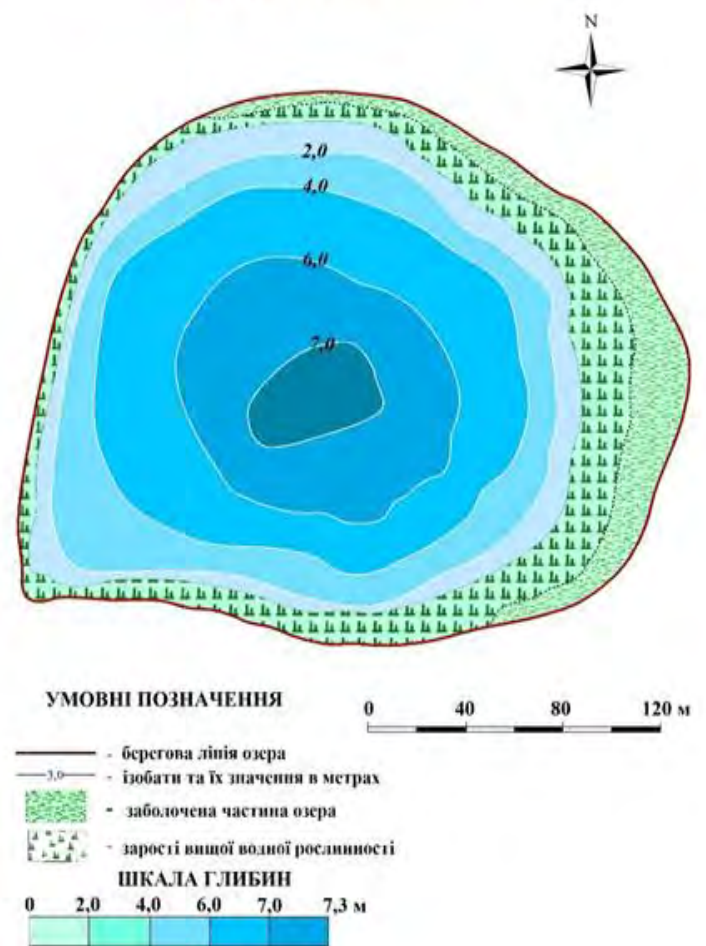

Озеро Святе

Рис. 6а. Батиметричні моделі озер Волинського Полісся 

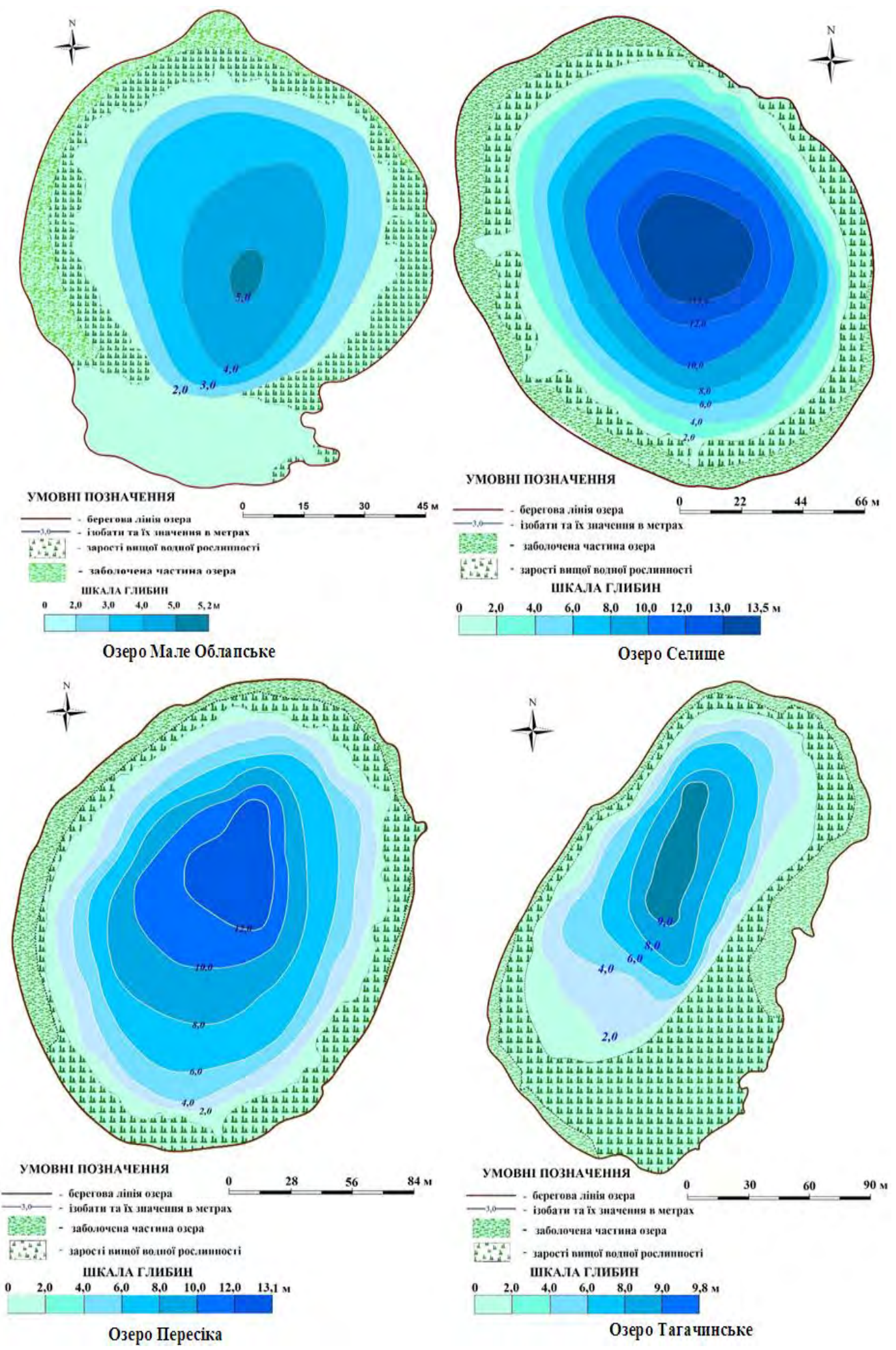

Рис. 6b. Батиметричні моделі озер Волинського Полісся 
Таблиця 2

Морфометричні та гідрологічні характеристики модельних озер

\begin{tabular}{|c|c|c|c|c|c|c|c|c|c|c|}
\hline Назва озера & $\begin{array}{l}{ }^{*} F, \\
2 a\end{array}$ & $\begin{array}{c}H_{\text {абс., }} \\
\mathcal{M}\end{array}$ & $\begin{array}{c}h_{c p,}, \\
M\end{array}$ & $\begin{array}{c}h_{\max .} \\
{ }_{\mathcal{M}}\end{array}$ & $\begin{array}{l}L, \\
\kappa M\end{array}$ & $\begin{array}{c}B_{\text {max. }}, \\
\kappa M\end{array}$ & $\begin{array}{c}B_{c p .}, \\
\kappa M\end{array}$ & $\begin{array}{c}l, \\
\kappa M\end{array}$ & $K_{n}$ & $K_{\text {вид. }}$ \\
\hline & 18,58 & 180,6 & 4,9 & 10,7 & 0,588 & 0,366 & 0,316 & 1,525 & 0,563 & 1,861 \\
\hline &, 18 & 36,3 & 5,9 & 7,5 &, 584 & 392 &, 363 & & & \\
\hline &, 34 & 79,8 & 1,5 & 7,7 & 497 & 370 & 0,329 & ,504 &, 593 & 1,511 \\
\hline & 5,06 & 32,3 & 3,9 & 733 & 494 & 392 & 0,325 & & & \\
\hline . & 2,53 & 170,4 & 2,1 & 5,5 & 0,185 & 0,165 & 0,137 & 0,635 & 0,640 & 1,350 \\
\hline & 25 & 77,0 & 5,4 & 13,5 & 288 & 233 & 0,217 & 917 & 582 & 1,327 \\
\hline &, 31 & 78,0 & 5,5 & 13,1 & 421 & 313 & 0,245 & 182 & 586 &, 718 \\
\hline & 9,43 & 179,6 & 4,3 & 9,8 &, 442 & 0,227 & 0,213 & 1,275 & & 2,075 \\
\hline Назва & $K_{\epsilon м \kappa .}$ & 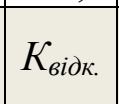 & $K_{\text {гл. }}$ & $\begin{array}{c}V_{\text {оз. }} \\
\text { тис.. }{ }^{3}\end{array}$ & $K$ & $\begin{array}{l}\Delta S \\
\kappa M^{2}\end{array}$ & $\begin{array}{l}* * W_{n p .,} \\
\text { тис.м. }\end{array}$ & $a_{\text {вод., }}$ & $\Delta a_{\text {вод., }}$ & $\begin{array}{c}A_{u,}, \\
\mathcal{M} \boldsymbol{M}\end{array}$ \\
\hline & 458 & 038 & 8,581 & \begin{tabular}{|l|}
790,0 \\
\end{tabular} & 0,209 & 4,785 & 112,3 & 0,142 & 7,035 & 887,64 \\
\hline Дол & 337 & 0,036 & 9,899 & 1260,0 & 0,265 & 3,774 & 100,9 & 0,080 & 2,488 & 1575,00 \\
\hline & & 109 & 2,747 & 245,0 & 0,217 & 4,601 & 94,6 &, 386 &, 590 & 326,67 \\
\hline & & 041 & 169 & 620,0 & 0,012 & 86,957 & 1766,0 & 848 & & 44,29 \\
\hline$e$ & 0,382 & 0,012 & 7,192 & 52,0 & 0,027 & 37,600 & 118,6 & & 0,438 & 55,32 \\
\hline & & ,012 & 13,568 & & & 7,460 & 59,3 & & & 23,40 \\
\hline & & 019 & 11,727 & & 0,061 & 16,311 & 212,0 & & & 39,29 \\
\hline Тагачинське & 0,439 & 0,022 & 9,451 & 380,0 & 0,086 & 11,596 & 137,5 & 0,362 & 2,764 & 348,62 \\
\hline
\end{tabular}

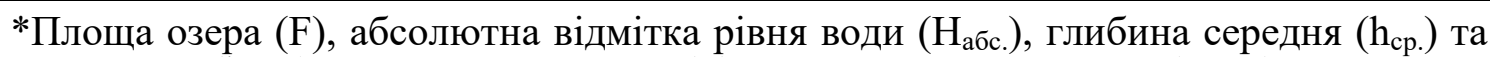
максимальна $\left(\mathrm{h}_{\text {max. }}\right)$, довжина водойми $(\mathrm{L})$, ширина максимальна $\left(\mathrm{B}_{\text {max. }}\right)$ та середня $\left(\mathrm{B}_{\mathrm{cp} .}\right)$, довжина берегової лінії (l), коефіцієнти - порізаності берегової лінії $\left(\mathrm{K}_{\text {п. }}\right)$, видовженості озера (К об'єм водних мас $\left(\mathrm{V}_{\text {оз. }}\right)$, показник площі $(\mathrm{K})$, питомий водозбір $(\Delta \mathrm{S})$, об'єм приточних вод 3 водозбору $\left(\mathrm{W}_{\text {пр. }}\right)$, умовний водообмін $\left(\mathrm{a}_{\text {вод. }}\right)$, питома

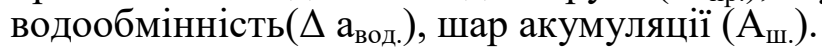

**Середньорічний модуль стоку, дм ${ }^{3} / \mathrm{c}_{\text {км}}^{2}-4,0$

За максимальною глибиною поширені такі озера: глибокі (15,01-25,0 м) - 1 шт., середньоглибокі (10,01-15,0 м) - 3 шт. та неглибокі (5,01-10,0 м) - 4 шт. Середні глибини озер знаходяться у межах 1,5-5,9 м. Максимальні довжини озер не перевищують 1 км (0,185-0,588 км), а середні - від 0,137 до 0,363 км. Довжини берегових ліній сягають від 0,635 км до 1,806 км. За об'ємом водних мас лише оз. Дольське має понад 1 млн. м ${ }^{3}$, інші озера - від 52,0 (оз. Мале Облапське) до 790,0 тис. м $^{3}$. У світлі глобальних змін клімату, що мають опосередкований зв'язок з рівневим режимом водойм, показник об'єму водних ресурсів сьогодні має стратегічне значення.

Нами розраховано низку коефіцієнтів (порізаності берегової лінії, видовженості, ємкості, відкритості, глибинності) озер та показників у системі «озеро-водозбір» (табл. 2), які важливі у порівнянні 3 іншими водоймами й вони мають увійти до кадастрової бази екологічних паспортів. 
Дешифрування космічних знімків озер для підготовки робочої основи цифрової батиметричної моделі дозволяє чітко виділити мілководні ділянки, що зазнають природних і антропогенних трансформацій. Як правило, такі ділянки акваторій озер заростають вищою водною рослинністю (макрофітами) або заболочуються, що суттєво впливає на оцінку показників площ водойм. Окремі дослідники при здійснені гідрографічної оцінки площ озер зараховують лише площі дзеркала водойми й нехтують заболоченими та зарослими макрофітами ділянками. Саме у цьому криється розбіжність в оцінці площ водойм уповільненого водообміну різними картографами. Дослідження показали, що шість озер мають ландшафтно-сукцесійні зміни площ своїх акваторій від 10,0 до 16,17\% (табл. 3).

Таблиця 3

Співвідношення площ водного дзеркала озера та заболочення і заростів вищої водної рослинності (ВВР)

\begin{tabular}{|l|c|c|c|}
\hline \multicolumn{1}{|c|}{ Назва озера } & $\begin{array}{c}\text { Площа дзеркала } \\
\text { води, га }\end{array}$ & $\begin{array}{c}\text { Заболочена } \\
\text { площа та } \\
\text { зарості ВВР, га }\end{array}$ & $\begin{array}{c}\text { Частка } \\
\text { ландшафтної } \\
\text { сукцесії, \% }\end{array}$ \\
\hline Велище & 18,34 & 0,24 & 1,31 \\
\hline Дольське & 19,82 & 1,36 & 6,86 \\
\hline Погоріле & 14,15 & 2,19 & 15,48 \\
\hline Святе & 14,15 & 1,91 & 13,50 \\
\hline Мале Облапське & 2,30 & 0,23 & 10,0 \\
\hline Селище & 5,38 & 0,87 & 16,17 \\
\hline Пересіка & 8,75 & 1,56 & 15,09 \\
\hline Тагачинське & 8,31 & 1,12 & 13,48 \\
\hline
\end{tabular}

Лише в оз. Велище частка ландшафтно-сукцесійних змін незначна й становить $1,31 \%$. Усі озера у периферійній частині оточені поясом макрофітів, які виступають своєрідним екологічним буфером щодо проникнення біогенних речовин у субліторальну зону водойми. Представлені вище батиметричні моделі озер виступають картографічною основою для побудови ландшафтних карт природних аквальних комплексів про які піде мова нижче.

\section{2. Ландшафтно-картографічне моделювання природних аквальних комплексів озер Поліського регіону}

У ландшафтознавстві озеро розглядається як природний аквальний комплекс (ПАК) рангу складного аквального урочища (акваурочища) ${ }^{17}$.

\footnotetext{
${ }^{17}$ Міллер Г.П., Петлін В.М., Мельник А.М. Ландшафтознавство : теорія і практика : навчальний посібник. Львів, 2002. 172 с.
} 
В складному акваурочищі, за методикою В. О. Мартинюка ${ }^{18,19}$, виділяємо низку підурочищ: літоральні, субліторальні, профундальні, пелагіальні. Відповідно аквапідурочища складаються з комплексу аквафацій, кожна 3 яких включає набір взаємозв'язаних і взаємообумовлених показників, що становлять єдиний ПАК. Виділення аквафацій грунтується на відмінностях мікрорельєфу і характеру складу та потужності донних відкладів (рис. 7), складу рослинних асоціацій, термічних особливостей ПАК. Морфологічна будова ПАК озера та критерії виділення аквапідурочищ та аквафацій наведено у табл. 4.

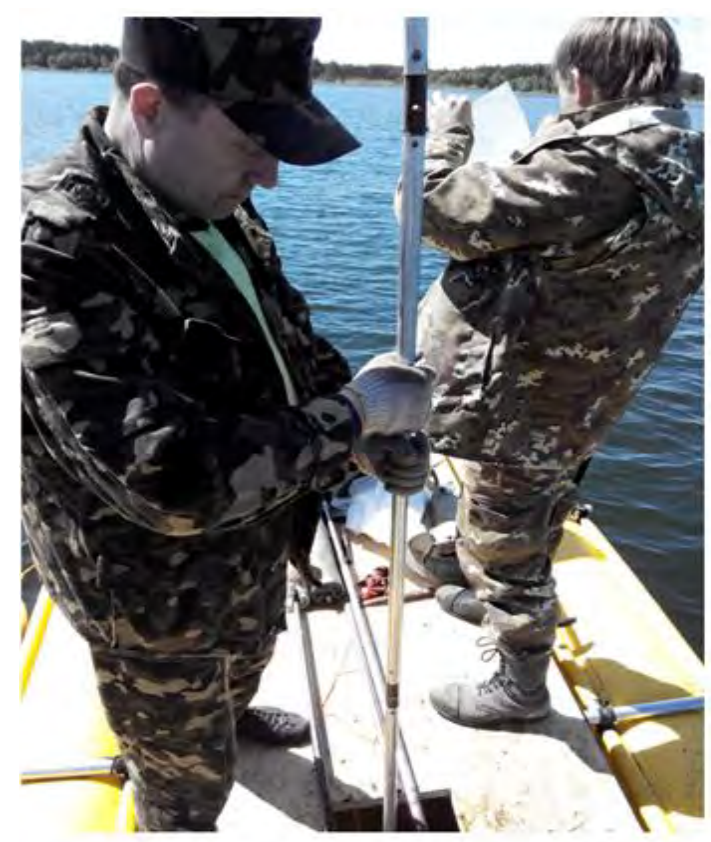

а) відбір проб озерних відкладів з платформи катамарана

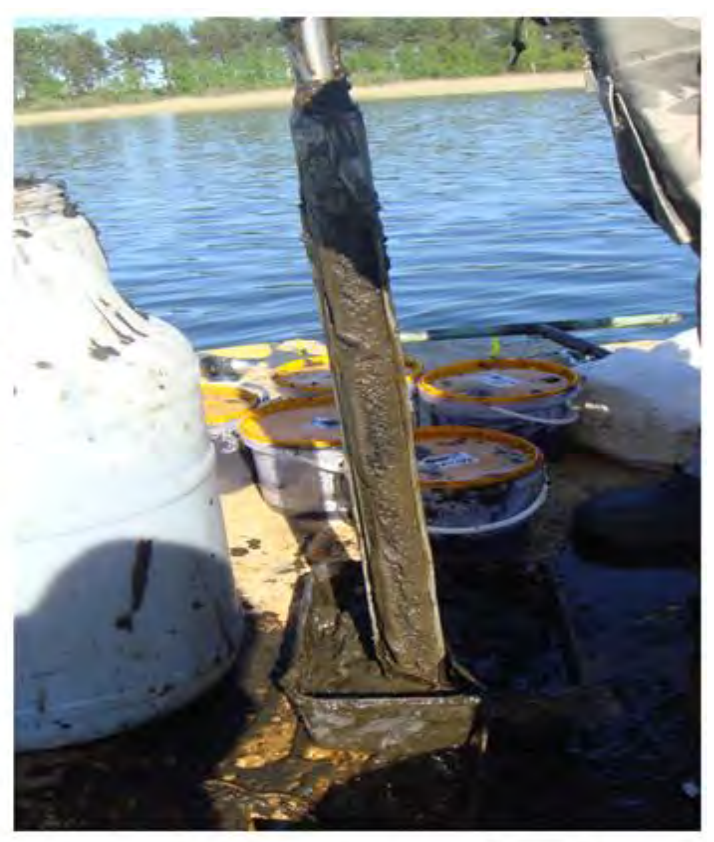

б) желеподібний вигляд донних відкладів озера на бурі ложкового типу

\section{Рис. 7. Відбір проб донних відкладів на оз. Засвяття (а-б, 07.05.2014)}

Слід наголосити, що пелагіальні аквапідурочища та їх аквафації виокремлюються за потужністю водного шару, термічною стратифікацією та гідродинамічними особливостями ПАК. На відміну від природних територіальних комплексів водозборів виділення ПАК має певні труднощі, в зв'язку із динамічними властивостями водного середовища, що складає матеріальну основу локальних комплексів (аквафацій) усіх рангів. Розглянемо ландшафтну будову та структуру ПАК деяких озер Волинського Полісся.

\footnotetext{
${ }^{18}$ Мартинюк В.О. Ландшафтний метод вивчення озер для цілей їх раціонального використання. Науковий вісник Волинського державного університету. Серія: Географічні науки. Луцьк, 1998. № 5. C. $49-51$.

19 Мартинюк В.О. Ландшафтно-лімнологічний аналіз басейнової (озерної) геосистеми. Наукові записки Тернопільського державного педагогічного університету. Серія «Географія». Тернопіль, 1999. № 2. С. 29-36. 
Таблиця 4

Морфологічна будова природних аквальних комплексів ${ }^{20}$

\begin{tabular}{|c|c|c|}
\hline $\begin{array}{c}\text { Морфологічна } \\
\text { одиниця }\end{array}$ & Критерії виділення & Основні процеси \\
\hline 1 & 2 & 3 \\
\hline $\begin{array}{l}\text { Складне } \\
\text { акваурочище } \\
\text { (озеро) }\end{array}$ & $\begin{array}{l}\text { Зовнішні межі (берег), загальний } \\
\text { стан озерної (лімнічної) системи. } \\
\text { Єдність функціонування озерної } \\
\text { системи: специфічного озерного } \\
\text { обміну речовини та енергії }\end{array}$ & $\begin{array}{l}\text { Окислювально-відновні; } \\
\text { накопичення речовини і } \\
\text { енергії; ритмічність }\end{array}$ \\
\hline Аквапідурочища & $\begin{array}{c}\text { Положення в рельєфі озерної } \\
\text { улоговини; характер донних } \\
\text { відкладів, відмінність у } \\
\text { функціонуванні }\end{array}$ & $\begin{array}{l}\text { Окислювально-відновні; } \\
\text { нако-пичення речовини і } \\
\text { енергії; ритмічність }\end{array}$ \\
\hline Літоральне & $\begin{array}{c}\text { Мілководдя: будова рельєфу; } \\
\text { обриси мілководь; характер } \\
\text { донних відкладів }\end{array}$ & $\begin{array}{l}\text { Окислювальні; } \\
\text { горизонтальне і вертикальне } \\
\text { перемішування водної } \\
\text { товщі; кластогенна і } \\
\text { хемогенна акумуляція; } \\
\text { розвиток бентальних } \\
\text { організмів; сезонна і добова } \\
\text { ритмічність }\end{array}$ \\
\hline $\begin{array}{l}\text { Ф а ц і ї (піщана, } \\
\text { глиниста, } \\
\text { мулиста, } \\
\text { карбонатна, } \\
\text { кам 'яниста } і \\
\text { галечникова) }\end{array}$ & $\begin{array}{l}\text { Характер мікрорельєфу, донних } \\
\text { відкладів; склад макрофітів }\end{array}$ & $\begin{array}{l}\text { Окислювальні; } \\
\text { горизонтальне і вертикальне } \\
\text { перемішування водної } \\
\text { товщі; кластогенна і } \\
\text { хемогенна акумуляція; } \\
\text { розвиток бентальних } \\
\text { організмів; сезонна і добова } \\
\text { ритмічність }\end{array}$ \\
\hline Субліторальне & $\begin{array}{c}\text { Глибина поширення; крутизна } \\
\text { схилів; характер донних } \\
\text { відкладів }\end{array}$ & $\begin{array}{l}\text { Окислювальні; схилові; } \\
\text { нако-пичення органо- } \\
\text { мінеральних і } \\
\text { біохемогенних осадів; } \\
\text { розвиток бентальних } \\
\text { організмів; сезонна і добова } \\
\text { ритмічність }\end{array}$ \\
\hline $\begin{array}{c}\text { Ф а ц і ї (піщано- } \\
\text { глиниста, } \\
\text { карбонатна, } \\
\text { мулиста) }\end{array}$ & $\begin{array}{l}\text { Характер мікрорельєфу, донних } \\
\text { відкладів; склад макрофітів }\end{array}$ & $\begin{array}{l}\text { Окислювальні; схилові; } \\
\text { нако-пичення органо- } \\
\text { мінеральних і } \\
\text { біохемогенних осадів; } \\
\text { розвиток бентальних } \\
\text { організмів; сезонна і добова } \\
\text { ритмічність }\end{array}$ \\
\hline
\end{tabular}

20 Мартинюк В.О., Ільїн Л.В. Ландшафтознавчий підхід дослідження озер. Наукові записки Тернопільського державного педагогічного університету. Серія : Географія. Тернопіль, 2002. № 2 (7). C. $77-83$. 
Закінчення табл. 4

\begin{tabular}{|c|c|c|}
\hline 1 & 2 & 3 \\
\hline Профундальне & $\begin{array}{c}\text { Потужність водного шару; } \\
\text { рельєф; характер донних } \\
\text { відкладів }\end{array}$ & $\begin{array}{l}\text { Окислювально-відновні, } \\
\text { схилові; накопичення } \\
\text { органо-мінеральних і } \\
\text { органічних відкладів; } \\
\text { сезонна ритмічність }\end{array}$ \\
\hline $\begin{array}{c}\text { Ф а ц і ї } \\
\text { (плоскохвиляста, } \\
\text { підняття ложа, } \\
\text { поглиблення } \\
\text { (западини) ложа) }\end{array}$ & $\begin{array}{c}\text { Характер мікрорельєфу, донних } \\
\text { відкладів }\end{array}$ & $\begin{array}{l}\text { Окислювально-відновні, } \\
\text { схилові; накопичення } \\
\text { органо-мінеральних і } \\
\text { органічних відкладів; } \\
\text { сезонна ритмічність }\end{array}$ \\
\hline Пелагіальне & Потужність водного шару & $\begin{array}{l}\text { Окислювально-відновні; } \\
\text { гідродинамічні; діяльність } \\
\text { планктонних організмів; } \\
\text { сезонна і погодна } \\
\text { ритмічність }\end{array}$ \\
\hline $\begin{array}{l}\text { Ф а ц і ї } \\
\text { (епілімніону, } \\
\text { металімніону, } \\
\text { гіполімніону) }\end{array}$ & $\begin{array}{c}\text { Гідротермічні і гідродинамічні } \\
\text { особливості }\end{array}$ & $\begin{array}{l}\text { Окислювально-відновні; } \\
\text { гідродинамічні; діяльність } \\
\text { планктонних організмів; } \\
\text { сезонна і погодна } \\
\text { ритмічність }\end{array}$ \\
\hline
\end{tabular}

Озеро Білинське розташоване в Любомльсько-Ковельському ФГР, за 6 км на північний схід від м. Ковель. Водойма локалізована в центральній частині с. Білин Ковельського району. Озеро $є$ невеликим за площею $\left(0,17\right.$ км$\left.^{2}\right)$, майже овальної форми. Уріз водної поверхні озера становить 174,0 м над рівнем моря, що на 8,5 м вище урізу води р. Турія, яка протікає за 5 км на захід від водойми. Довжина озера 0,56 км, ширина максимальна 0,43 км, а середня - 0,30 км. Максимальна глибина води 3,1 м, середня - 1,91 м. Обсяг водних мас озера становить 288,0 тис. км ${ }^{3}$. Озеро безстічне. Основне джерело живлення озера - атмосферні опади. Донні відклади периферійної частини озера представлені торф'яноболотними, піщано-мулистими відкладами, а центральної частини органо-вапняковим сапропелем i його різновидами. Потужність сапропелю озерної улоговини в окремих місцях досягає 9,0 м, а середня 3,82 м (рис. 8).

Сапропелеві відклади зондувальної точки А озера є високозольними (у \% на суху речовину) й становлять на різних глибинах керну від $31,0 \%$ $\left(5,5\right.$ м) до $60,0 \%$ (1,5 м). Уміст сполук $\mathrm{Fe}_{2} \mathrm{O}_{3}$ (у \% на суху речовину) варіює на різних горизонтах керну від 1,16\% (7,0 м) до 2,01\% (2,5 м). За результатами польових досліджень нами побудовано ландшафтну карту оз. Білинське (рис. 9). 


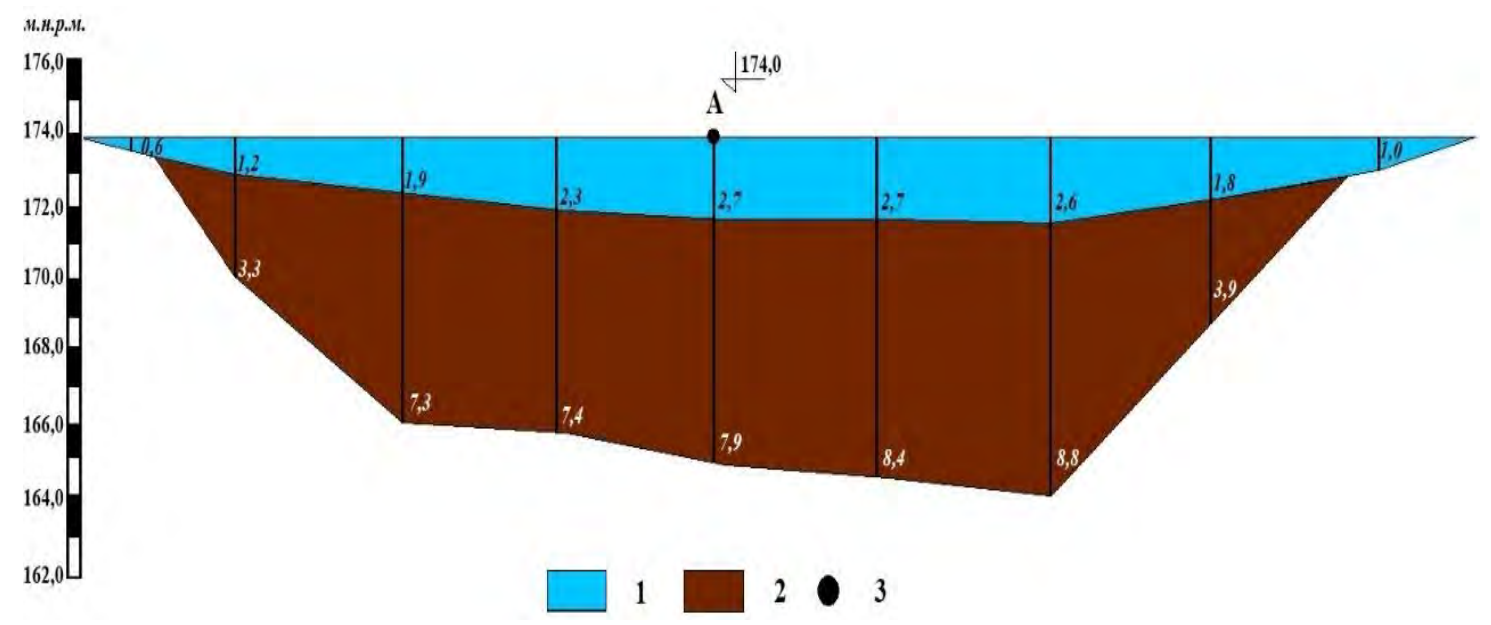

\section{Рис. 8. Співвідношення потужності донних відкладів та водних мас оз. Білинське}

Умовні позначення: 1 - вода, 2 - сапропель органо-вапняковий, 3 - пункт зондування донних відкладів

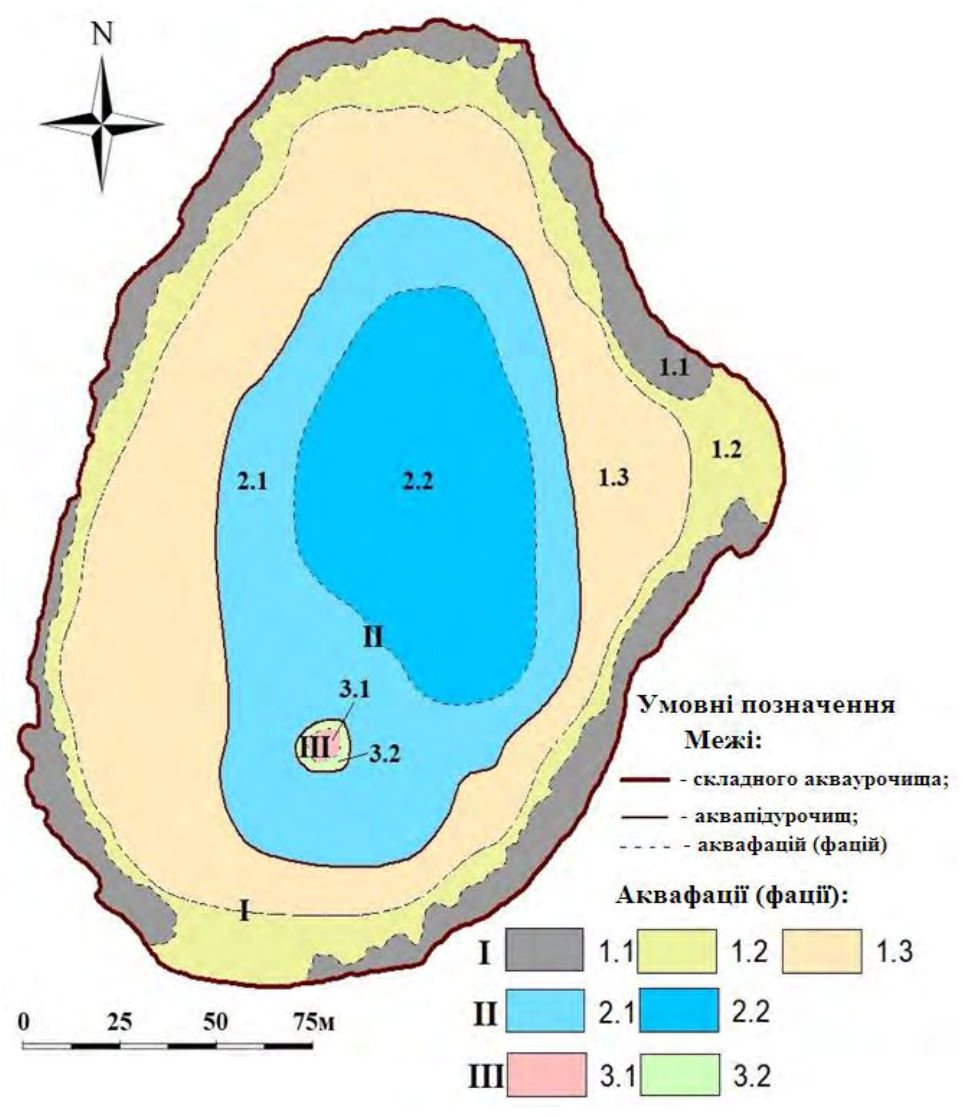

\section{Рис. 9. Ландшафтна структура оз. Білінське}

21 Андрийчук С.В. Ландшафтная модель природно-аквального комплекса озера Белинское (Волынское Полесье). Устойчивое развитие: региональные аспекты : сборник мат-лов XII Междун. научно-практ. конф. молодых ученых, г. Брест, 23-24 апреля 2020 г. / Брест. гос. ун-т им. А. С. Пушкина ; редкол.: М.А. Богдасаров, И.В. Абрамова, Т.А. Шелест. Брест : БрГУ, 2020. С. 78-80. Деп. в ГУ БелИСА 12 июня 2020 г. № Д202014. 
Легенда до рис. 9:

І. Літоральне аквапідурочище на торф'яно-болотних i піщаномулисто-сапропелевих відкладах, що сформувалися на алювіальних пісках з видовою різноманітністю надводних і підводних макрофітів.

Аквафаціï: 1.1. Літоральні акумулятивні торф'яно-болотні, очеретяноаїрово-рогозово-ситникові, без температурної стратифікації. 1.2. Літоральні абразійно-акумулятивні відкритих ділянок мілководь піщаномулисті, які підстеляються органо-вапняковим сапропелем малопотужні (до 1,5 м) з розрідженою вищою водною рослинністю, без температурної стратифікації. 1.3. Літоральні акумулятивно-транзитні органовапняково-сапропелеві мало- (1,5-3,0 м) і середньопотужні (3,0-5,0 м), розріджених вільно плаваючих водоростей, без температурної стратифікації.

II. Субліторально-профундальне аквапідурочище на органовапняково-сапропелевих відкладах, які підстеляються крейдомергельними породами, зі збідненим видовим різноманіттям рослинних угруповань.

Аквафації: 2.1. Субліторальні транзитно-акумулятивні органовапняково-сапропелеві потужні $(5,0-7,0$ м), розріджених вільно плаваючих водоростей, без температурної стратифікації. 2.2. Профундальні акумулятивні органо-вапняково-сапропелеві дуже потужні (понад 7,0 м), поодиноких вільно плаваючих водоростей, без температурної стратифікації.

III. Урочище озерного острова, вкрите вербово-чагарниковими угрупованнями на торф'яно-болотних грунтах i піщано-мулистих озерних відкладах.

Фащиï: 3.1. Острівні підняті елювіальні, вкриті чагарниковою рослинністю і лучним різнотрав'ям на торф'яно-болотних грунтах. 3.2. Острівні прибережні, 3 дуже пологими схилами $\left(1-3^{\circ}\right)$, транселювіальні піщано-мулисті, які в паводки затоплюються водою, вкриті очеретяно-рогозовими угрупованнями.

У ПАК оз. Білинське ми виділили два аквапідурочища, зокрема літоральне та субліторально-профундальне, а також урочище озерного острова, який періодично підтоплюється водою. Літоральне аквапідурочище загальною площею 10,51 га $(61,82 \%)$ представлено трьома видами аквафацій включаючи шість ландшафтних контурів. Субліторально-профундальне аквапідурочище менше за площею 6,41 га (37,71\%). Воно представлено двома видами аквафацій, що відрізняються потужністю сапропелевих відкладів. Детально ландшафтометричні показники ПАК озера наведені в табл. 5.

Озеро Біле (с. Біле) розташоване у Нижньостирському ФГР Волинського Полісся та приурочене до місцевостей високих межиріч із 
плосковерхими горбами та грядами, складених водно-льодовиковими пісками 3 близьким заляганням крейдо-мергелів. Площа водойми складає 0,75 км² $^{2}$ Озеро доволі глибоке, максимальна глибина становить 20,5 м, середня - 12,16 м. Довжина водойми 1,40 км, ширина максимальна 0,71 км, середня - 0,55 км. Озеро безстічне. Об'єм водних мас озера становить 9156,0 тис. м $^{3}$. Створена ландшафтна карта оз. Біле та наведена на рис. 10.

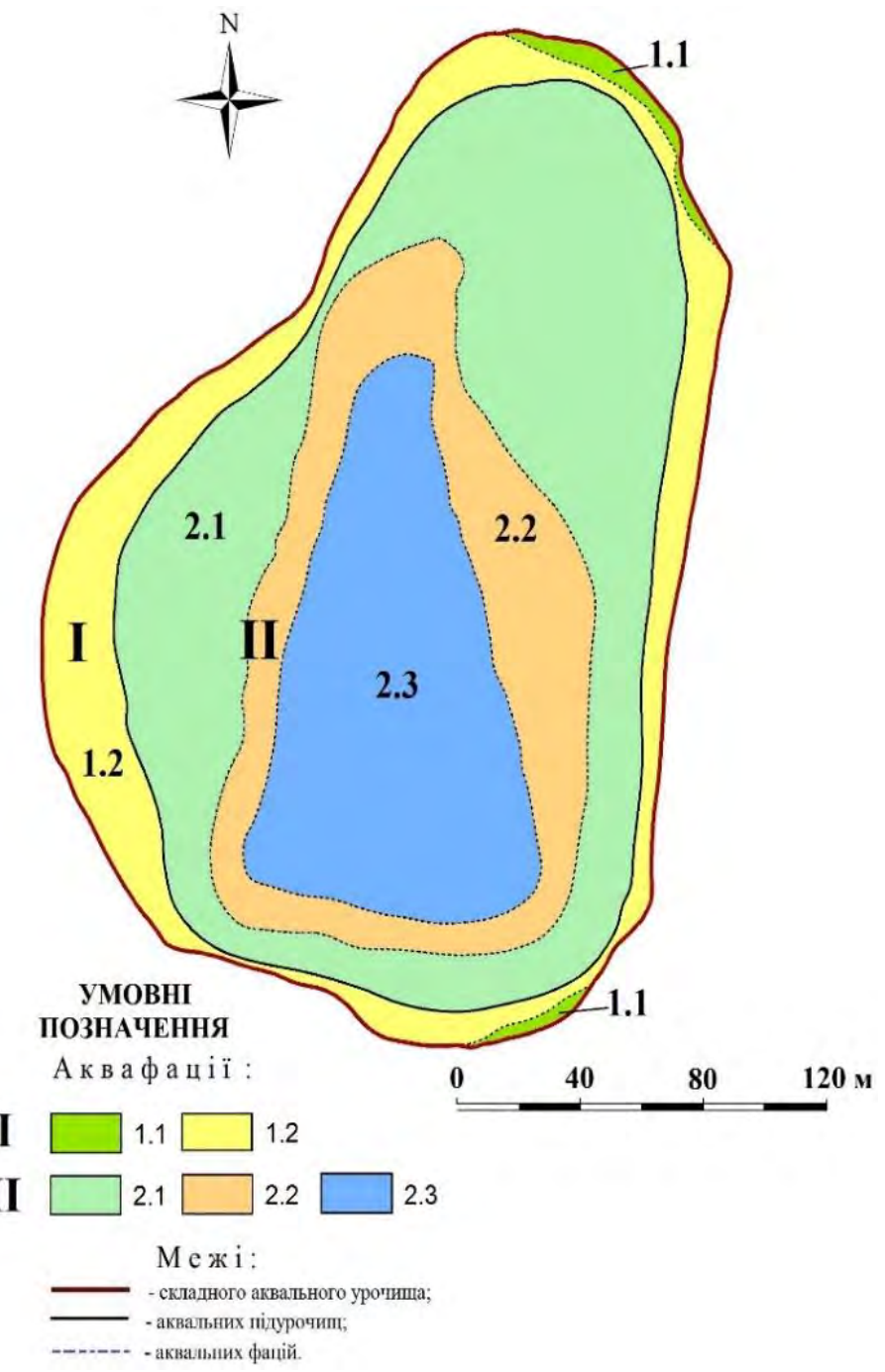

Рис. 10. Ландшафтна структура оз. Біле

Легенда до рис. 10:

І. Літорально-субліторальне аквапідурочище на алювіальних пісках, фрагментарно вкрите макрофітами та підводною рослинністю.

Аквафаміï: 1.1. Мілководні акумулятивно-абразійні піщані та піщаномулисті очеретяно-осокових асоціацій 3 однорідним температурним режимом, частково антропогенно модифіковані. 1.2. Субліторальні 
акумулятивно-транзитні з крутими $\left(20-30^{\circ}\right)$ схилами озерної улоговини піщані та мулисто-піщані елодеєво-харових та розріджених осокових асоціацій 3 однорідним температурним режимом, антропогенно модифіковані.

\section{II. Профундальне підурочище на піщаних та сапропелевих} відкладах, що сформувалися на алювіальних пісках.

Аквафамії: 2.1. Профундальні транзитно-акумулятивні піщані сапропелеві малопотужні (0-2,0 м) розріджених нитчасто-харовоелодеєвих асоціацій з чіткою сезонною температурною стратифікацією. 2.2. Профундальні транзитні піщані сапропелеві мало- та середньопотужні (2,0-4,0 м) з поодинокими зануреними водоростями та з чіткою сезонною температурною стратифікацією. 2.3. Глибоководні акумулятивні піщані сапропелеві, що сформувалися на органо-глинистих сапропелях середньопотужні (4,0-5,0 м) з майже відсутніми гідрофітами та 3 чіткою сезонною температурною стратифікацією.

У ПАК оз. Біле виділено літорально-субліторальне та профундальне аквапідурочища. Улоговина озера із досить крутими схилами й тому літорально-субліторальне аквапідурочище посідає незначну площу $(17,26 \%)$, де виокремили лише два види аквафацій з трьома контурами. Центральну глибоководну частину улоговини ПАК озера займає профундальне аквапідурочище (82,74\%), де виділено три види аквафацій. Середня площа аквафацій у даному ПАК становить 12,55 га (табл. 5). Аквафації виділу 2.3 підстеляються органо-глинистим середньопотужним (4,0-5,0 м) сапропелем, який сформувався на крейдо-мергельних породах. Середня зольність сапропелю (у \% на суху речовину) становить $62,20 \%$. Південна частина ПАК зазнає антропогенних модифікацій 3 боку присадибних господарств с. Біле.

Озеро Озерянське (с. Озеряни) розташоване у ТурійськоРожищенському ФГР й приурочене до місцевостей зандрових рівнин із зеленомоховими i чорничниковими сосняками 3 домішкою дрібнолистяних порід на дерново-слабо- i середньопідзолистих грунтах, частково розорані. Водойма $є$ складовою загальнозоологічного заказника місцевого значення площею 2736,0 га утвореного за рішенням Волинської облради народних депутатів від 21.10.1991 р., № 226 й відноситься до ДП «Турійське ЛГ» Радовичівського лісництва. У заказнику охороняються сосново-дубові, березово-осикові ліси до 85 років (1361 га); 12 озер карстового походження (67 га): Пересіка, Гняльбище, Панське, Погоріле, Бережисте, Болотне, Озерянське, Пісочне, Зміїнець та інші; болота (44 га); чагарникові зарості (26,0 га); лучні угіддя, пасовища (830 га) та інші землі ${ }^{22}$.

\footnotetext{
${ }^{22}$ Природно-заповідний фонд Волинської області. URL: http://eco.voladm.gov.ua (дата звернення: 10.07.2020).
} 
Площа оз. Озерянське 0,18 км² $^{2}$ Довжина озера 0,615 км, ширина максимальна 0,396 км, середня - 0,293 км. Глибина озера максимальна 7,9 м, середня - 3,4 м. Берегова лінія слабо порізана, чітко виражена. Довжина берегової лінії становить 1,651 км. Озеро стічне; з північної частини водойми витікає канал, який з'єднує каскад із чотирьох озер. Об'єм водних мас становить 330,7 тис. м³. Донні відклади периферійної частини озера представлені торф'яно-болотними та піщано-мулистими осадами, а від ізобати 1,5 м - органо-вапняковим сапропелем. Площа озера, яка вкрита сапропелем (за матеріалами Київської ГРЕ) становить

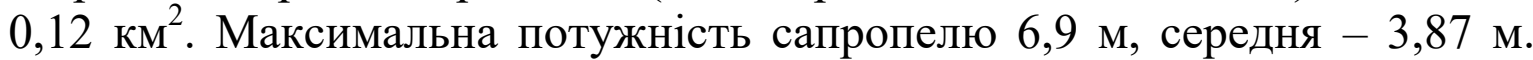
Товща пелогену складає близько 0,30 м. Запаси сапропелю при середній вологості $82,93 \%$ складають 479,9 тис.м ${ }^{3}$, а у перерахунку на умовну $60,0 \%$ вологість 223,0 тис. т. Близько $60,0 \%$ озерної улоговини заповнено сапропелевими відкладами. Середній уміст (у \% на суху речовину) сполук $\mathrm{Fe}_{2} \mathrm{O}_{3}$ в сапропелі становить $0,78 \%, \mathrm{CaO}-23,71 \%$, зольності $-50,0 \%$. За результатами польових досліджень нами складена ландшафтно-картографічна модель оз. Озерянське (рис. 11).

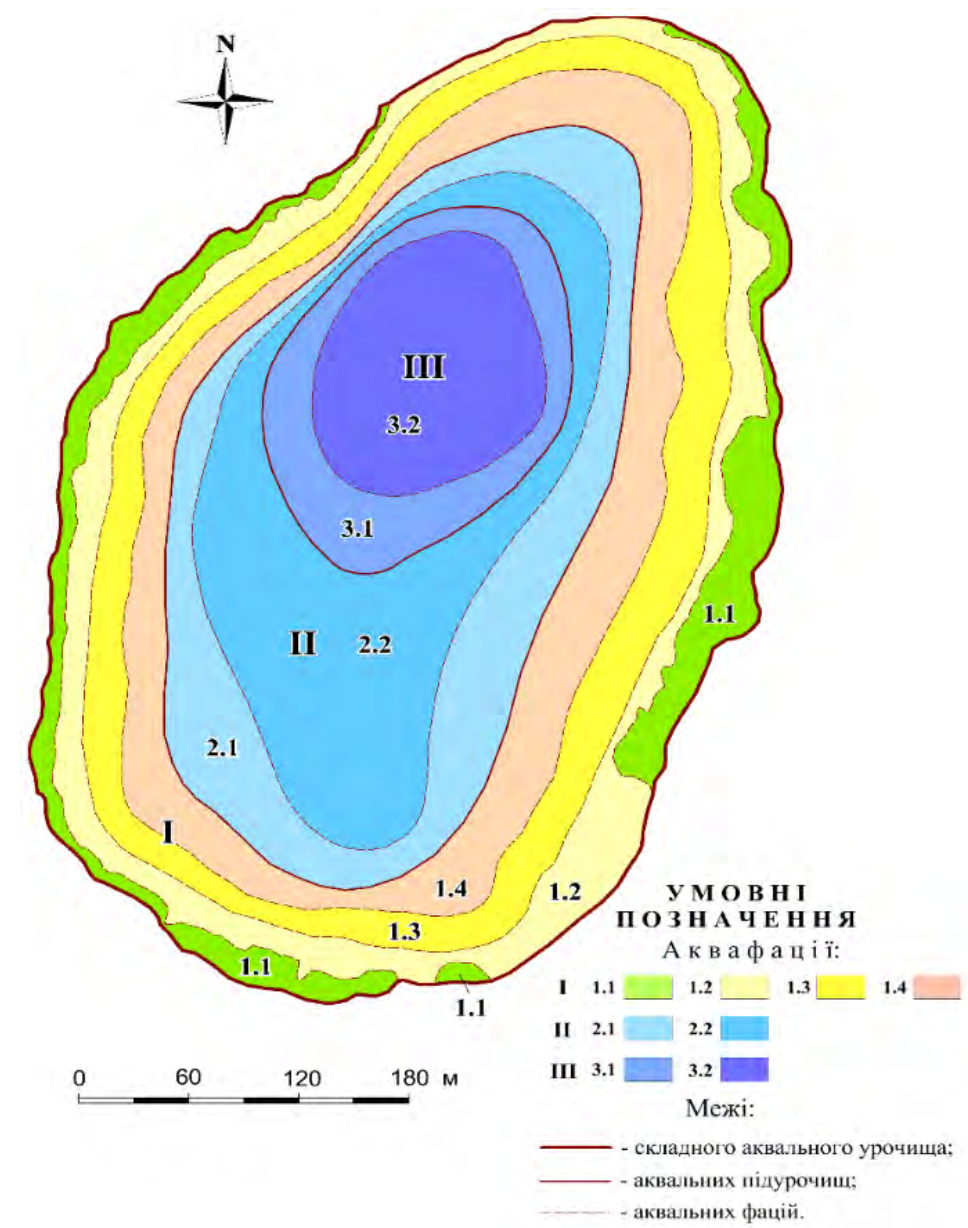

Рис. 11. Ландшафтна структура ПАК оз. Озерянське 
Легенда до рис. 11:

І. Літоральне аквапідурочище на торф'яно-болотних i піщаномулисто-сапропелевих відкладах, що сформувалися на алювіальних пісках з видовим різноманіттям надводних і підводних макрофітів.

Аквафаціï: 1.1. Літоральні акумулятивні торф'яно-болотні, очеретянорогозово-ситникові, без температурної стратифікації. 1.2. Літоральні акумулятивно-абразійні піщані та піщано-мулисті, елодейно-рдесниково-стрілолистові, без температурної стратифікації. 1.3. Літоральні акумулятивно транзитні піщано-мулисті, що підстеляються органовапняковим сапропелем малопотужні (0,50-1,5 м), пухирникововодоперицево-куширові, без температурної стратифікації. 1.4. Літоральні транзитно-акумулятивні органо-вапняково-сапропелеві малопотужні (1,5-2,5 м), рясково-нитчасто-харові, без температурної стратифікації.

II. Субліторальне аквапідурочище на органо-вапняково-сапропелевих відкладах зі збідненим видовим різноманіттям рослинних угруповань.

Аквафації: 2.1. Субліторальні акумулятивно-транзитні органовапняково-сапропелеві середньопотужні (2,5-3,5 м), розріджених вільно плаваючих водоростей, без температурної стратифікації. 2.2. Субліторальні транзитно-акумулятивні органо-вапняково-сапропелеві середньопотужні (3,5-4,5 м), поодиноких плаваючих водоростей, без температурної стратифікації.

III. Профундальне аквапідурочище карстового заглиблення озерного ложа на органо-вапняковому сапропелі, що підстеляються крейдо-мергельними відкладами зі збідненим видовим різноманіттям рослинних угруповань.

Аквафащіï: 3.1. Профундальні акумулятивні органо-вапняковосапропелеві середньопотужні та потужні (4,5-5,5 м), поодиноких вільно плаваючих водоростей та неоднорідним температурним режимом влітку. 3.2. Профундальні акумулятивні органо-вапняково-сапропелеві потужні (понад 5,5 м), що підстеляються крейдо-мергельними породами, 3 практично відсутньою водною рослинністю та неоднорідним температурним режимом влітку.

У ПАК озера виокремлено три види аквапідурочищ, зокрема літоральне $(53,87 \%$ площі), субліторальне $(31,07 \%)$ та профундальне $(15,05 \%)$. У літоральному аквапідурочищі на основі диференціації літологічного складу донних відкладів та ландшафтно-геохімічних i геофізичних процесів виділено чотири види аквафацій із шістьма контурами. Літоральне аквапідурочище зазнає суттєвих природних та антропогенних трансформацій, які проявляються через заболочування, 
заростанням макрофітами (9,09\% площі) прибережних ділянок ПАК, зниження рівня води озера під час тривалих посух, винесення біогенних речовин зі схилових ділянок водозбору у водойму тощо. У субліторальному та профундальному аквапідурочищах виділено лише по два види аквафацій. Більш детально ландшафтометрична характеристика ПАК наведена у табл. 5.

Озеро Чисте розташоване у Верхньоприп’ятському ФГР Волинського Полісся. Водойма приурочена до першої надзаплавної тераси p. Прип'ять, яка ускладнена піщаними дюнами із чорничниковозеленомоховими сосновими лісами. «Озеро Чисте» - гідрологічний заказник площею 58,0 га, який утворений за розпорядженням Волинської обласної ради народних депутатів від 03.03.1993, № 18-p. Головним об'єктом природоохоронної діяльності $\epsilon$ озеро серед соснового лісу віком понад 50 років 3 домішкою берези повислої (Betula pendula), трав'яний ярус якого формують зелені мохи (Bryophyta) і ягідники: чорниця миртолиста (Vaccinium myrtillus), буяхи звичайні (Vaccinium uliginosum), брусниця звичайна (Vaccinium vitis-idaea $)^{23}$.

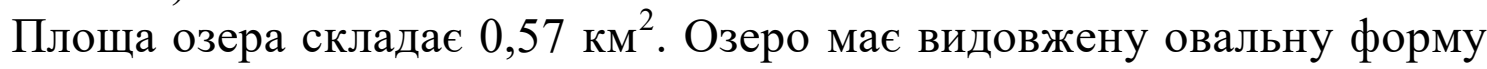
й простягається 3 південного-заходу на північний схід. Довжина озера 1,18 км, ширина середня - 0,48 км, максимальна - 0,61 км. Максимальна глибина водойми становить 5,5 м, а середня $-2,87$ м. Озеро безстічне, але підземним стоком воно гідрологічно пов'язане 3 p. Прип'ять і Турським каналом. Довжина берегової лінії становить 2,96 км. Об’єм водних мас озера складає 905,0 тис. м³. Схили улоговини озера круті. Максимальна потужність донних відкладів (за даними Київської ГРЕ) становить 16,3 м, а середня потужність 6,23 м. Озерні відклади представлені піщаними, піщано-мулистими та сапропелевими, зокрема ціанофіцейним, зоогеново-водоростевим та органо-глинистим. Площа зайнята сапропелем становить 31 га (54,39\%) озера. Об’єм сапропелю водойми складає 1620 тис. м³. Таким чином, 64,16\% об'єму озерної улоговини заповнені відкладами сапропелю $^{24}$. За результатами польових лімнологічних та геокомплексних досліджень нами створена ландшафтна модель ПАК оз. Чисте (рис. 12).

\footnotetext{
${ }^{23}$ Природно-заповідний фонд Волинської області. URL: http://eco.voladm.gov.ua (дата звернення: 10.07.2020).

${ }^{24}$ Мартинюк В.О, Андрійчук С.В. Еколого-ландшафтне моделювання озер природоохоронних територій Волинського Полісся. Туризм: наука, освіта, практика : мат-ли II Міжн. наук.-практ. конф. 3 нагоди 50-ої річниці створення Рівненського відділу УГТ у НУВГП, м. Рівне, 24-25 квітня 2020 р. $/$ редкол.: В.С. Мошинський, Н.Б. Савіна, М.О. Клименко, С.І. Коротун та ін. Рівне : НУВГП, 2020. C. $125-131$.
} 


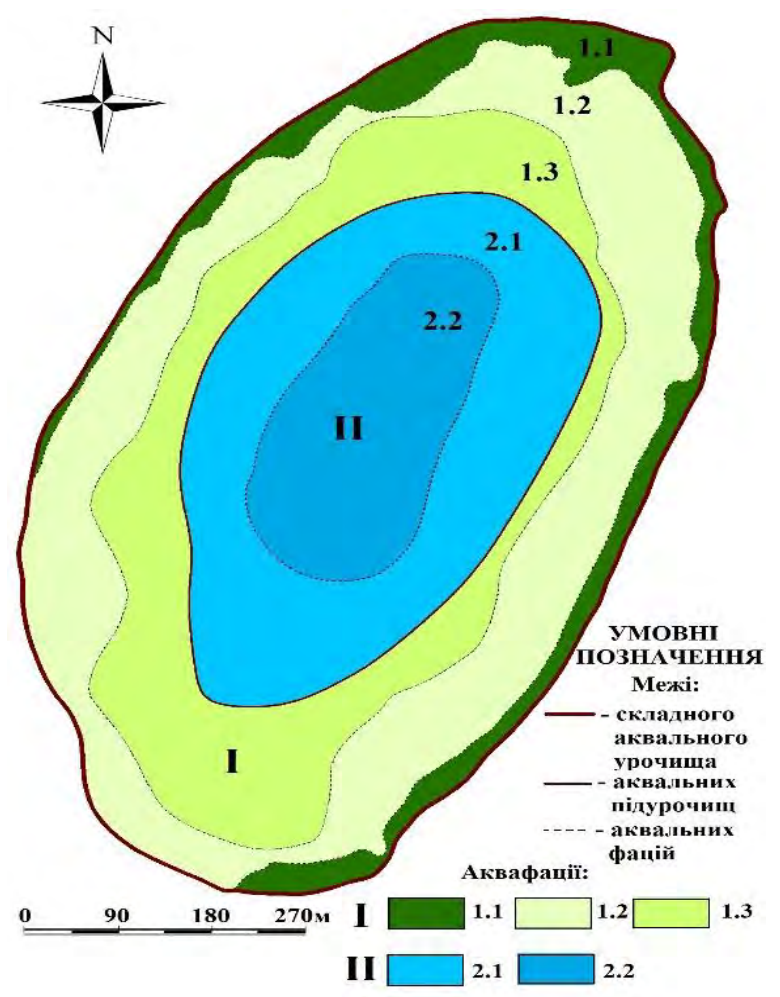

Рис. 12. Ландшафтна структура ПАК оз. Чисте ${ }^{25}$

Легенда до рис. 12:

I. Літоральне аквапідурочище на піщано-мулистих та сапропелевих відкладах, що сформувалися на алювіальних пісках 3 видовим різноманіттям надводних і підводних макрофітів.

Аквафащіï: 1.1. Літоральні акумулятивні піщано-мулисті малопотужні (до 0,5 м) осоково-очеретяно-рогозові, без температурної стратифікації. 1.2. Літоральні акумулятивно-абразійні піщані та супіщані малопотужні (до 0,4 м) рдесниково-куширові та локально елодейні, без температурної стратифікації. 1.3. Літоральні акумулятивно-транзитні ціаноцифейносапропелеві мало- та середньопотужні $(0,5-5,0$ м) 3 розрідженою підводною рослинністю, без температурної стратифікації.

II. Субліторально-профундальне аквапідурочище на органосилікатно-сапропелевих відкладах, що підстеляються алювіальними пісками зі збідненим видовим різноманіттям підводної рослинності.

Аквафащії: 2.1. Субліторальні транзитно-акумулятивні ціанофіцейні, що підстеляються зоогеново-водоростевим сапропелем потужні (5,0-11,0 м) поодиноких плаваючих водоростей й добовою температурною неоднорідністю. 2.2. Профундальні акумулятивні ціанофіцейні,

25 Мартинюк В.О, Андрійчук С.В. Еколого-ландшафтне моделювання озер природоохоронних територій Волинського Полісся. Туризм: наука, освіта, практика : мат-ли II Міжн. наук.-практ. конф. 3 нагоди 50-ої річниці створення Рівненського відділу УГТ у НУВГП, м. Рівне, 24-25 квітня 2020 р. $/$ редкол.: В.С. Мошинський, Н.Б. Савіна, М.О. Клименко, С.І. Коротун та ін. Рівне : НУВГП, 2020. С. $125-131$. 
що підстеляються зоогеново-водоростевим та органо-глинистим сапропелем дуже потужні (понад 11,0 м) зі збідненою підводною рослинністю й добовою температурною неоднорідністю.

У ПАК озера виокремлено два аквапідурочища, зокрема літоральне (64,5\% площі) та субліторально-профундальне (35,5\%). Літоральне аквапідурочище включає три види аквафацій, а субліторальнопрофундальне 3 двома видами аквафацій - глибоководну частину ложа ПАК. Складність територіального розчленування ПАК наведена у табл. 5.

Аналіз ландшафтометричних показників чотирьох ПАК показав, що озера Білинське та Озерянське мають більш строкату будову. Принаймні, за кількістю ландшафтних контурів (по 10 шт.) досить помітно. Обидва ПАК мають майже однакову площу і приблизно однакову середню площу $(1,700-1,774$ га) виділів. Найвищий індекс подрібненості (щільність контурів або їхня кількість на одиницю площі) у ПАК оз. Білинське $(0,588)$, а найнижчий в оз. Біле $(0,079)$. Відношення кількості ландшафтних контурів ПАК до середньої площі ландшафтних контурів (коефіцієнт складності) показав, що найвищим цей коефіцієнт $\epsilon$ в оз. Білинське $(5,882)$, а найнижчим в оз. Чисте $(0,437)$. Найвищий коефіцієнт ландшафтної роздрібненості $(0,900)$ у ПАК озер Білинське та Озерянське, а найнижчий в оз. Чисте $(0,800)$. Згідно оцінки гідрологічних параметрів, які розглядалися вище, а також ландшафтометричних характеристик (табл. 5) найвищий потенціал саморозвитку має оз. Біле.

Таблиця 5

Ландшафтометрична характеристика ПАК модельних озер Волинського Полісся

\begin{tabular}{|c|c|c|c|c|c|c|c|c|c|c|c|}
\hline \multicolumn{2}{|c|}{ Вид ПАК } & \multicolumn{2}{|c|}{$\begin{array}{c}\text { Площа виду } \\
\text { ПАК (га) }\end{array}$} & \multicolumn{2}{|c|}{$\begin{array}{c}\text { \% площі виду } \\
\text { від загальної } \\
\text { площі }\end{array}$} & \multirow{2}{*}{ 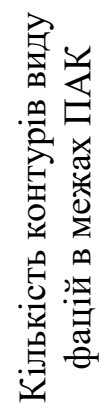 } & \multirow{2}{*}{ 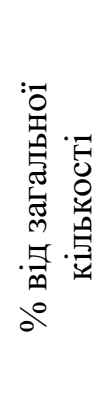 } & \multirow{2}{*}{ 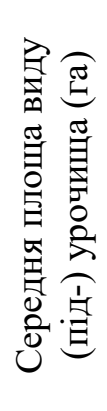 } & \multirow{2}{*}{ 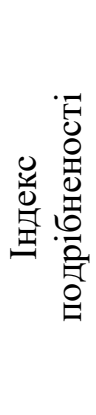 } & \multirow{2}{*}{ 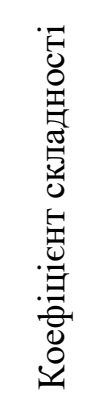 } & \multirow{2}{*}{ 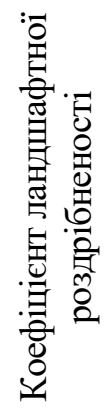 } \\
\hline 志罡 & $\cdot \stackrel{\cdot a}{\vec{\Xi}}$ & 点息 & 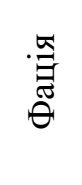 & 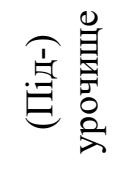 & $\begin{array}{l}. \breve{G} \\
\ddot{\theta}\end{array}$ & & & & & & \\
\hline 1 & 2 & 3 & 4 & 5 & 6 & 7 & 8 & 9 & 10 & 11 & 12 \\
\hline \multicolumn{12}{|c|}{ ПАК оз. Білинське (с. Білин) } \\
\hline \multirow[t]{4}{*}{ I } & & 10,51 & & 61,82 & & 6 & 60,0 & 1,75 & 0,571 & 3,429 & 0,833 \\
\hline & 1.1 & & 2,22 & & 13,06 & & & & & & \\
\hline & 1.2 & & 2,52 & & 14,82 & & & & & & \\
\hline & 1.3 & & 5,77 & & 33,94 & & & & & & \\
\hline \multirow[t]{3}{*}{ II } & & 6,41 & & 37,71 & & 2 & 20,0 & 3,21 & 0,312 & 0,624 & 0,499 \\
\hline & 2.1 & & 3,77 & & 22,18 & & & & & & \\
\hline & 2.2 & & 2,64 & & 15,53 & & & & & & \\
\hline
\end{tabular}


Закінчення табл. 5

\begin{tabular}{|c|c|c|c|c|c|c|c|c|c|c|c|}
\hline 1 & 2 & 3 & 4 & 5 & 6 & 7 & 8 & 9 & 10 & 11 & 12 \\
\hline III* & & 0,08 & & 0,47 & & 2 & 20,0 & 0,04 & 25,0 & 50,0 & 0,500 \\
\hline & 3.1 & & 0,03 & & 0,18 & & & & & & \\
\hline & 3.2 & & 0,05 & & 0,29 & & & & & & \\
\hline \multicolumn{2}{|c|}{ Усього } & 17,0 & 17,0 & 100,0 & 100,0 & 10 & 100,0 & 1,700 & $\mathbf{0 , 5 8 8}$ & $\mathbf{5 , 8 8 2}$ & 0,900 \\
\hline \multicolumn{12}{|c|}{ ПАК оз. Біле (с. Біле) } \\
\hline \multirow[t]{3}{*}{ I } & & 13,00 & & 17,26 & & 3 & 50,00 & 4,33 & 0,231 & 0,698 & 0,667 \\
\hline & 1.1 & & 1,0 & & 1,32 & & & & & & \\
\hline & 1.2 & & 12,0 & & 15,94 & & & & & & \\
\hline \multirow[t]{4}{*}{ II } & & 62,3 & & 82,74 & & 3 & 50,00 & 20,77 & 0,048 & 0,144 & 0,667 \\
\hline & 2.1 & & 32,2 & & 42,76 & & & & & & \\
\hline & 2.2 & & 13,3 & & 17,67 & & & & & & \\
\hline & 2.3 & & 16,8 & & 22,31 & & & & & & \\
\hline \multicolumn{2}{|c|}{ Усього } & 75,3 & 75,3 & 100,0 & 100,0 & 6 & 100,0 & 12,55 & $\mathbf{0 , 0 7 9}$ & 0,476 & $\mathbf{0 , 8 3 3}$ \\
\hline \multicolumn{12}{|c|}{ ПАК оз. Озерянське (с. Озеряни) } \\
\hline \multirow[t]{5}{*}{ I } & & 9,558 & & 53,87 & & 6 & 60,00 & 1,593 & 0,628 & 3,766 & 0,833 \\
\hline & 1.1 & & 1,613 & & 9,09 & & & & & & \\
\hline & 1.2 & & 2,212 & & 12,47 & & & & & & \\
\hline & 1.3 & & 2,757 & & 15,54 & & & & & & \\
\hline & 1.4 & & 2,976 & & 16,77 & & & & & & \\
\hline \multirow[t]{3}{*}{ II } & & 5,513 & & 31,07 & & 2 & 20,00 & 2,757 & 0,363 & 0,725 & 0,500 \\
\hline & 2.1 & & 2,564 & & 14,45 & & & & & & \\
\hline & 2.2 & & 2,949 & & 16,62 & & & & & & \\
\hline \multirow[t]{3}{*}{ III } & & 2,671 & & 15,05 & & 2 & 20,00 & 1,336 & 0,749 & 1,497 & 0,500 \\
\hline & 3.1 & & 1,139 & & 6,42 & & & & & & \\
\hline & 3.2 & & 1,532 & & 8,63 & & & & & & \\
\hline \multicolumn{2}{|c|}{ Усього } & 17,742 & 17,742 & 100,00 & 100,00 & 10 & 100,00 & 1,774 & 0,564 & 5,637 & 0,900 \\
\hline 1 & 2 & 3 & 4 & 5 & 6 & 7 & 8 & 9 & 10 & 11 & 12 \\
\hline \multicolumn{12}{|c|}{ ПАК оз. Чисте (с. Броди) } \\
\hline \multirow[t]{4}{*}{ I } & & 36,90 & & 64,50 & & 3 & 60,00 & 12,30 & 0,081 & 0,244 & 0,667 \\
\hline & 1.1 & & 5,26 & & 9,19 & & & & & & \\
\hline & 1.2 & & 18,18 & & 31,78 & & & & & & \\
\hline & 1.3 & & 13,47 & & 23,54 & & & & & & \\
\hline \multirow[t]{3}{*}{ II } & & 20,31 & & 35,50 & & 2 & 40,00 & 10,16 & 0,098 & 0,197 & 0,500 \\
\hline & 2.1 & & 13,42 & & 23,45 & & & & & & \\
\hline & 2.2 & & 6,89 & & 12,05 & & & & & & \\
\hline \multicolumn{2}{|c|}{ Усього } & 57,21 & 57,21 & 100,00 & 100,00 & 5 & 100,00 & 11,44 & 0,087 & 0,437 & 0,800 \\
\hline
\end{tabular}

*Острівне урочище

\section{ВИСНОВКИ}

Батиметричне моделювання озер Поліського регіону із застосуванням ГІС-технологій дозволило сформувати уяву про мікрорельєф озерних улоговин та крутизну їхніх схилів, особливості розміщення карстових западин та лійок, площі літоральних зон. Такі цифрові моделі $\epsilon$ додатковим аргументом щодо обгрунтування генезису озер, вони слугують картографічною основою інформаційно-кадастрової бази про водойми уповільненого водообміну регіону. 
Результати батиметричних досліджень показали, що шість озер (Погоріле, Святе, Мале Облапське, Селище, Пересіка, Тагачинське) мають ландшафтно-сукцесійні зміни площ своїх акваторій від 10,0 до $16,17 \%$. Такі зміни пов'язані як з природними (глобальні зміни клімату) так і з антропогенними (осушувальна меліорація, забір води з підземних горизонтів, каналізоване водовідведення тощо) чинниками.

Ландшафтні карти ПАК озер $\epsilon$ важливим комплексним документом, який синтезує дані про батиметрію озерної улоговини, особливості гідродинаміки водойми (абразія), геохімічні процеси (акумуляція, транзит), літологію донних відкладів та їхню потужність, вищу водну рослинність (макрофіти) та підводні угруповання, температурний режим тощо. Легенди ландшафтних карт є до певної міри типовими щодо повторюваності літоральних, субліторальних, профундальних та пелагіальних аквапідурочищ, а також їхніх перехідних видів. Відмінності ПАК озер у першу чергу зумовлені літологічним складом та особливостями озерних відкладів, вони $є$ провідними чинниками диференціації аквафацій.

Найбільш строкату будову мають ПАК озер Білинське та Озерянське у яких виділено по 10 ландшафтних контурів. Висока диференціація морфологічної будови ПАК озер спостерігається у літоральних та літорально-субліторальних аквапідурочищах. Саме у цих локальних ПАК відбуваються інтенсивні ландшафтно-сукцесійні процеси. Нами встановлено, що у більшості досліджуваних ПАК озер на початковому етапі формування їхніх улоговин карстові процеси були домінуючими.

Наведені у роботі батиметричні моделі та ландшафтні карти із лімнолого-метричними параметрами озер мають стати картографічною основою майбутніх екологічних паспортів озер. Подальші дослідження будуть спрямовані на розробку природно-господарських моделей цілісних озерно-басейнових систем регіону із обгрунтуванням їхнього збалансованого природокористування.

\section{АНОТАЦІя}

Актуалізується необхідність розробки сучасних методів кадастроворесурсної оцінки озер Поліського регіону, яка грунтується на створенні батиметричних моделей, ландшафтних карт i лімнометричних параметрів водойм. Здійснено історичний екскурс лімнологічних, у тому числі й батиметричних, досліджень озер Поліського регіону, зокрема Волинського Полісся. На основі польових лімнологічних досліджень, проведених у 2010-2019 рр., наведено дев'ять батиметричних моделей озер Волинського Полісся та три гідрологічні профілі (на прикладі озера Посвітське). Проаналізовано морфометричні й гідрологічні параметри озер та обгрунтовано особливості ландшафтно-сукцесійних процесів 
водойм. Створено цифрові ландшафтні карти озер Білинське (с. Білин), Біле (с. Біле), Озерянське (с. Озеряни), Чисте (с. Броди) й визначено основні ландшафтометричні характеристики (площі аквафацій, кількість контурів, індекс подрібненості, коефіцієнти складності й ландшафтної роздрібненості) природного аквального комплексу. Запропоновано використання батиметричних моделей i ландшафтних карт для майбутніх екологічних паспортів озер. Дослідження мають стати основою для розробки цілісних природно-господарських моделей озерно-басейнових систем регіону з відповідною спеціалізацією свого розвитку.

\section{ЛІТЕРАТУРА}

1. Альохіна О.В., Корусь М.М., Кошовий В.В., Мельник М.М., Муравський Л.І., Сидорук І.В., Юрчук П.В. Батиметричні дослідження озера Світязь: минуле, сучасність та перспективи. Природа Західного Полісся та прилеглих територій. 2014. № 11. С. 24-32.

2. Андрийчук С.В. Ландшафтная модель природно-аквального комплекса озера Белинское (Волынское Полесье). Устойчивое развитие: региональные аспекты : сборник мат-лов XII Междун. научно-практ. конф. молодых ученых, г. Брест, 23-24 апреля 2020 г. Брест : БрГУ, 2020. С. 78-80. Деп. в ГУ БелИСА 12 июня 2020 г. № Д202014.

3. Dobrowolski R., Bałaga K., A. Bogucki et al. Chronostratigraphy of the Okunin and Czerepacha lake-mire geosystems (Volhynia Polesiye, NW Ukraine) during the late glacial and holocene. Geochronometria. 2001. Vol. 20. P. 107-115.

4. Зубкович I.В., Мартинюк В.О. Особливості антропогенного навантаження на ландшафти Волинського Полісся у контексті геоекологічної діагностики озерно-басейнових систем. Actual problems of natural sciences: modern scientific discussions : collective monograph. Riga : Izdevniecība "Baltija Publishing", 2020. P. 220-242. DOI: https://doi.org/ 10.30525/978-9934-588-45-7.13

5. Зубкович I.В., Мартинюк В.О. Особливості ландшафтної структури Волинського Полісся (за результатами польових досліджень на ключових ділянках). Наукові записки Сумського ДПУ імені А.С. Макаренка. Серія «Географічні науки». 2020. Том 2. Вип. 1. С. 3-18. DOI: doi.org/10.5281/zenodo.3727228.

6. Ільїн Л.В. Сучасний стан, динаміка, конструктивні основи раціонального використання та охорони озер Волинської області : дис. ... канд. геогр. наук : 11.00 .11 ; Львів. держ. ун-т ім. Івана Франка. Львів, 1996. 258 с. 
7. Ільїн Л.В., Мартинюк Л.В. Озера України : довідник. Львів : Ред.-видав. відділ Львів. держ. ун-ту, 1998. 52 с.

8. Ільїн Л.В., Мольчак Я.О. Озера Волині : Лімно-географічна характеристика. Луцьк : Надстир'я, 2000. 140 с.

9. Ільїн Л.В. Лімнокомплекси Українського Полісся : монографія : У 2-х т. Т. 1: Природничо-географічні основи дослідження та регіональні закономірності. Луцьк : РВВ «Вежа» Волин. нац. ун-ту імені Лесі Українки, 2008. 316 с.

10. Kondracki J. Katalog jezior poleskich. Prace, wykonane w zakladzie geogr. Universytety w Warszawe. 1938. № 24. S. 19-35.

11. Lenzewicz St. Miedzyrzecze Bugu i Prypeci. Wody plynace i jeziora. Przeglad geogr. 1931. T. 11. S. 5-28.

12. Мартинюк В.О. Ландшафтний метод вивчення озер для цілей їх раціонального використання. Науковий вісник Волинського державного університету. Серія: Географічні науки. Луцьк, 1998. № 5. С. 49-51.

13. Мартинюк В.О. Ландшафтно-лімнологічний аналіз басейнової (озерної) геосистеми. Наукові записки Тернопільського державного педагогічного університету. Серія «Географія». Тернопіль, 1999. № 2. C. 29-36.

14. Мартинюк В.О, Андрійчук С.В. Еколого-ландшафтне моделювання озер природоохоронних територій Волинського Полісся. Туризм: наука, освіта, практика : матеріали II Міжн. наук.-практ. конф. 3 нагоди 50-ої річниці створення Рівненського відділу УГТ у НУВГП, м. Рівне, 24-25 квітня 2020 р. / редкол. В.С. Мошинський та ін. Рівне : НУВГП, 2020. C. $125-131$.

15. Мартинюк В.О., Зубкович I.В., Андрійчук С.В. Батиметричне моделювання озер Волинського Полісся для потреб їхнього ландшафтного картографування. Географія та екологія: наука і освіта : збірник матеріалів 8 Всеукр. наук.-практ. конф. 3 міжнар. участю, м. Умань, 9-10 квітня 2020 р. Умань : Візаві, 2020. С. 116-121.

16. Мартинюк В.О., Ільїн Л.В. Ландшафтознавчий підхід дослідження озер. Наукові записки Тернопільського державного педагогічного університету. Серія: Географія. Тернопіль, 2002. № 2 (7). С. 77-83.

17. Міллер Г.П., Петлін В.М., Мельник А.М. Ландшафтознавство : теорія і практика : навчальний посібник. Львів, 2002. 172 с.

18. Природно-заповідний фонд Волинської області. URL: http://eco.voladm.gov.ua (дата звернення: 10.07.2020).

19. Проць Г.Л., Зденюк М.В. Ландшафтно-лімнологічні дослідження Шацького поозер'я. Вісник Львів. ун-ту. Серія «Географія». 1980. Вип. 12. С. 72-77. 
20. Проць Г.Л., Карпенко Н.И., Худзик С.Р. и др. Ландшафтные картосхемы озер Люцимер и Черное. Вестник Львов. ун-та. Серія «Геологія». 1986. Вып. 9. С. 11-14.

21. Rühle E. Jeziora krasowe zachodniej czesci Polesia Wołyńskiego. Rocznik Wolynski. Równe, 1935. T. IV. S. 210-241.

22. Трофимчук О.М., Мокрий В.I., Радчук В.В., Радчук I.В., Загородня С.А. Інформаційне забезпечення гідроакустичного моніторингу озер Західного Полісся. Екологічна безпека та природокористування. Київ, 2015. Вип. 1 (17). С. 5-15.

23. Choiński A., Ilyin L., Ptak M., Strzelczak A. Zmiana batymetrii jeziora Świtaź w latach 1929-2012. Природа Західного Полісся та прилеглих територій. Луцьк, 2012. № 9. С. 55-59.

\section{Information about authors: Martyniuk V. O.,}

Candidate of Geographical Sciences, Associate Professor, Professor at the Department of Ecology, Geography and Tourism

Rivne State University of Humanities

12, Stepana Bandery str., Rivne, 33028, Ukraine

Andriichuk S. V.,

Postgraduate at the Department of Ecology, Geography and Tourism Rivne State University of Humanities 12, Stepana Bandery str., Rivne, 33028, Ukraine Zubkovych I. V., Postgraduate at the Department of Ecology, Geography and Tourism Rivne State University of Humanities 12, Stepana Bandery str., Rivne, 33028, Ukraine 